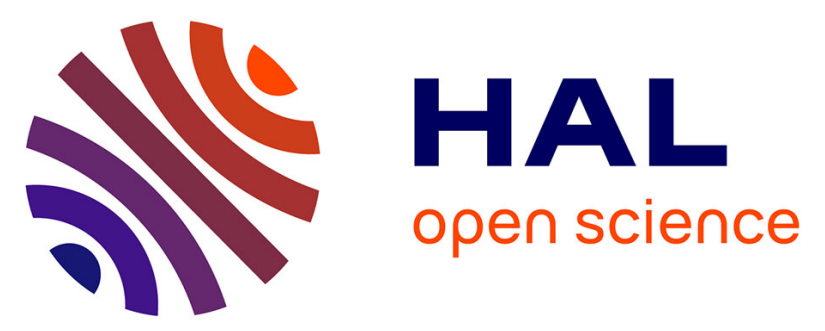

\title{
Assimilation of sulfate and carbonaceous rocks: experimental study, thermodynamic modeling and application to the Noril'sk-Talnakh region (Russia)
}

Giada Iacono-Marziano, Clément Ferraina, Fabrice Gaillard, Ida Di Carlo, Nicholas T. Arndt

\section{To cite this version:}

Giada Iacono-Marziano, Clément Ferraina, Fabrice Gaillard, Ida Di Carlo, Nicholas T. Arndt. Assimilation of sulfate and carbonaceous rocks: experimental study, thermodynamic modeling and application to the Noril'sk-Talnakh region (Russia). Ore Geology Reviews, 2017, 90, pp.399-413. 10.1016/j.oregeorev.2017.04.027 . insu-01518297

\section{HAL Id: insu-01518297 \\ https://hal-insu.archives-ouvertes.fr/insu-01518297}

Submitted on 4 May 2017

HAL is a multi-disciplinary open access archive for the deposit and dissemination of scientific research documents, whether they are published or not. The documents may come from teaching and research institutions in France or abroad, or from public or private research centers.
L'archive ouverte pluridisciplinaire HAL, est destinée au dépôt et à la diffusion de documents scientifiques de niveau recherche, publiés ou non, émanant des établissements d'enseignement et de recherche français ou étrangers, des laboratoires publics ou privés.

\section{(1) $(1) \Theta$}

Distributed under a Creative Commons Attribution - NonCommercial - NoDerivatives| 4.0 


\section{Accepted Manuscript}

Assimilation of sulfate and carbonaceous rocks: experimental study, thermodynamic modeling and application to the Noril'sk-Talnakh region (Russia)

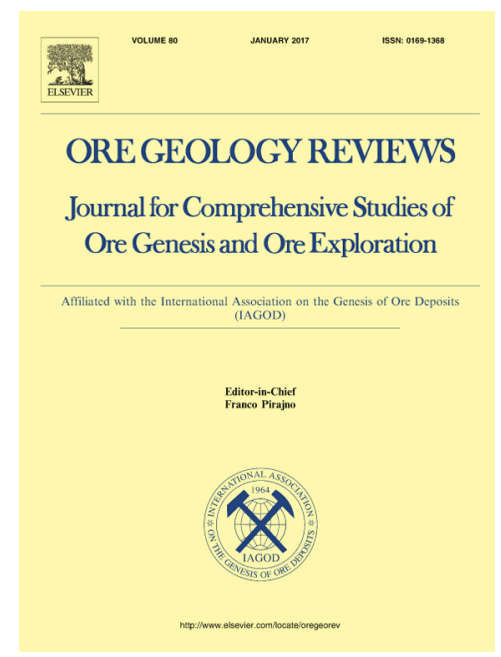

Giada Iacono-Marziano, Clément Ferraina, Fabrice Gaillard, Ida Di Carlo, Nicholas T. Arndt

PII: S0169-1368(16)30785-5

DOI: http://dx.doi.org/10.1016/j.oregeorev.2017.04.027

Reference: OREGEO 2195

To appear in:

Ore Geology Reviews

Received Date:

2 December 2016

Revised Date:

13 April 2017

Accepted Date:

27 April 2017

Please cite this article as: G. Iacono-Marziano, C. Ferraina, F. Gaillard, I. Di Carlo, N.T. Arndt, Assimilation of sulfate and carbonaceous rocks: experimental study, thermodynamic modeling and application to the Noril'skTalnakh region (Russia), Ore Geology Reviews (2017), doi: http://dx.doi.org/10.1016/j.oregeorev.2017.04.027

This is a PDF file of an unedited manuscript that has been accepted for publication. As a service to our customers we are providing this early version of the manuscript. The manuscript will undergo copyediting, typesetting, and review of the resulting proof before it is published in its final form. Please note that during the production process errors may be discovered which could affect the content, and all legal disclaimers that apply to the journal pertain. 


\title{
Assimilation of sulfate and carbonaceous rocks: experimental study, thermodynamic modeling and application to the Noril'sk-Talnakh region (Russia).
}

\author{
Giada IACONO-MARZIANO ${ }^{\text {* }}$, Clément FERRAINA ${ }^{a}$, Fabrice GAILLARD ${ }^{\text {a }}$, Ida DI CARLO ${ }^{\text {a }}$ \\ and Nicholas T. ARNDT ${ }^{\text {b }}$ \\ aISTO, UMR 7327 CNRS-Université d'Orléans-BRGM, 1A rue de la Ferollerie, 45071 Orléans Cedex 2, \\ France \\ ${ }^{\mathrm{b}}$ ISTerre, UMR 5275 CNRS-Université Grenoble Alpes, 38041 Grenoble Cedex 9 Saint Martin d'Hères, \\ France \\ *corresponding author, Giada.lacono@cnrs-orleans.fr
}

\section{$\underline{\text { Abstract }}$}

Most of the intrusions in the Noril'sk-Talnakh region (Siberia) are hosted in thick sedimentary sequences including abundant evaporitic and terrigenous sedimentary rocks. Three mafic-ultramafic intrusions in this region contain unusually thick massive sulfide deposits, which represent one of the world's largest economic concentrations of $\mathrm{Ni}, \mathrm{Cu}$ and PGE. The interaction of Siberian magmas with sulfate and organic matter-rich sedimentary rocks has been proposed as a possible mechanism for the origin of these exceptional sulfide deposits but the interaction process and the reaction paths have never been fully investigated. Here we clarify, by both experimental petrology and thermodynamic modeling, how sulfate and organic matter assimilation occur in mafic-ultramafic magmas, affecting magma composition, crystallization and sulfide saturation.

Interaction experiments were conducted at conditions relevant to the emplacement of Noril'sk type intrusions ( $1200{ }^{\circ} \mathrm{C}, \sim 80 \mathrm{MPa}$ ) to simulate the assimilation of sulfate and/or organic compounds by ultramafic magmas. We used a picrite from Noril'sk1 intrusion, and coal and anhydrite from the area as starting materials. The experimental results show that the incorporation of anhydrite into the magma occurs by chemical dissolution in the melt, which increases the magma's sulfur content, but suppresses sulfide saturation and reduces olivine crystallization. Extreme assimilation leads to sulfate saturation in the magma and high dissolved sulfur contents of $0.9 \pm 0.1 \mathrm{wt} . \% \mathrm{~S}$. Conversely, coal assimilation promotes sulfide segregation and magma crystallization, while decreasing the dissolved $\mathrm{H}_{2} \mathrm{O}$ content of the melt and increasing the amount of coexisting fluid phase.

We also employed gas-melt thermodynamic calculations to quantify the effect of these assimilations on the redox conditions and the $S$ content of the magma, and investigate the role of temperature, pressure, and initial gas content of the magma in the assimilation process. We quantify how sulfate assimilation strongly oxidizes the magma and increases its $\mathrm{S}$ content; both effects are intensified by 
increasing pressure (from 50 to $100 \mathrm{MPa}$ in this study), decreasing temperature (from 1350 to 1200 ${ }^{\circ} \mathrm{C}$ in this study), and decreasing amounts of fluid phase initially coexisting with the magma (from 2 to 0 wt.\%). The interaction with organic matter $(\mathrm{CH}$ in this study) induces a strong reduction of the magma, even for extremely low degrees of assimilation (few tenths of wt. \%), and the dehydration of the melt.

We therefore suggest that in the Noril'sk-Talnakh district (1) additional S was supplied to mantle derived magmas by the assimilation of evaporitic rocks, and was transported during magma ascent in the form of dissolved, oxidized $S$; (2) a substantial reduction of the magma inducing sulfide segregation and important crystallization then occurred due to the interaction with carbonaceous sediments. This mechanism can potentially produce massive sulfide deposits by important sulfate assimilation (locally higher than $3 \mathrm{wt} . \% \mathrm{CaSO}_{4}$ ) and minor organic matter assimilation (few tenths of wt.\% $\mathrm{CH}$ ); however, if one of the two steps does not occur, or the assimilation in (1) is not large enough, disseminated sub economic or no sulfide deposits are produced. We conclude that exceptional conditions favoring substantial assimilation of sediments are needed to generate exceptional ore deposits like those of the Noril'sk-Talnakh district.

Keywords: magmatic sulfides; Noril'sk-Talnakh intrusions; magma-sediment interaction; experimental petrology; thermodynamic modeling.

\section{Introduction}

The Noril'sk-Talnakh region is located at the northwestern corner of the Siberian platform (Fig.1a), and comprises one of the largest economic concentrations of $\mathrm{Ni}, \mathrm{Cu}$, PGE-enriched magmatic sulfides. The sulfide deposits of the Noril'sk and Talnakh ore districts present several unique features: (i) they are concentrated in a relatively small area (8x18 km in extent), (ii) they are important for both Ni-Cu and PGE, and (iii) they exceed all other magmatic deposits in the amounts of economically valuable metals per ton of ore (Naldrett 2004 and references therein).

The Noril'sk-Talnakh volcanic sequence belongs to the Siberian Traps and, together with the Maymecha-Kotuy basin, represents one of the two areas in which both magmatic and volcanic activities are the most intense and variable in composition (Naldrett 2004 and references therein). More than $3500 \mathrm{~m}$ of volcanic rocks were erupted in this region in the Late Permian-Early Triassic (Czamanske et al. 1995 and references therein). Intrusions represent 6.5\% of the magmatic rocks in this area (Fedorenko 1994), and most of them are associated to the Noril'sk-Kharealakh fault and, to a lesser extent, to the Imangda fault, which both extend to the base of the crust (Rempel 1994). 
Several types of intrusions are recognized in this region on the basis of their petrographic, geochemical and field characteristics (e.g. Czamanske et al. 1995; Naldrett 2004; Sluzhenikin et al. 2014); these classifications varying from one author to another are not discussed here. Ore deposits are only found in differentiated (layered) mafic-ultramafic intrusions, but not all differentiated maficultramafic intrusions host ore deposits. Some of them do not host any sulfide mineralization (i.e. the Fokinsky type; Czamanske et al. 1995; Sluzhenikin et al. 2014), and most of them contain disseminated sulfides more or less enriched in metal elements (i.e. the Zubovsky, and Lower Talnakh types; Zen'ko and Czamanske 1994a; Naldrett 2004; Sluzhenikin et al. 2014). In particular, Chernogorsky-subtype intrusions (e.g. Chernogorka, Noril'sk II, Tangarelakh, Imangda) are almost identical to the ore-bearing intrusions in their internal construction, but contain only sub-economic, sulfide disseminations (Zen'ko and Czamanske 1994b; Czamanske et al. 1995). Only 3 out of at least 22 mafic-ultramafic intrusions contain massive sulfide ore deposits and are mined: these are the Noril'sk 1, the Talnakh, and the Kharaelakh intrusions, called Talnakh type by Naldrett (2004), or the Noril'sk type by Czamanske et al. (1995) and Sluzhenikin et al. (2014). Their emplacement is contemporaneous with the peak of the volcanic activity (Kamo et al. 1996, 2003).

Most of the intrusions in the Noril'sk-Talnakh region are hosted by sedimentary sequences, Cambrian to Permian in age, which are far thicker in this region than in the remainder of the Siberian platform ( 5000 m; Czamanske et al. 1995; Naldrett 2004). The Noril'sk area was a north-south trending trough during the late Proterozoic; it experienced important subsidence during the Paleozoic accompanied by three cycles of marine transgression and regression followed by the deposition of terrigenous, coal-bearing sediments (Rempel 1994; Simonov et al. 1994). The sedimentary sequence is overlaid by thick (up to $3500 \mathrm{~m}$ ) Siberian Trap lavas, Upper Permian to Lower Triassic in age, which have been partially eroded. The intrusions were emplaced at shallow depths and are considered as sub-volcanic, or even as magma conduits to the overlying volcanism (e.g. Czamanske et al. 1995; Naldrett et al. 1996; Arndt et al. 2003; Naldrett 2004). Intrusions containing massive sulfide ore bodies are ribbon shaped and hosted in Lower Devonian to Upper Permian sedimentary rocks (Fig.1b, c): the Noril'sk 1 intrusion is emplaced in the Carboniferous-Permian Tungusskaya Series and in the overlying volcanic sequence (Fig.1c); the Talnakh intrusion in the Tungusskaya Series and the upper Devonian Kalargonsky formation (constituted of dolomites, limestones and dolomitic marls; Fig.1c); and the Kharaelakh intrusion in the Manturovsky (dolomites, anhydrites, marls), Razvedochninsky, and Kureysky (marls; Fig.1c) lower Devonian formations (Zen'ko and Czamanske 1994b; Czamanske et al. 1995; Naldrett 2004; Sluzhenikin et al. 2014). Both the Tungusskaya series and the Razvedochninsky formation are made up of terrigenous rocks; the former is composed of rhythmically alternating coal-bearing terrigenous rocks and coal seams with thickness from 0.5 to 15 
$\mathrm{m}$, the latter of argillites and mudstones (Zen'ko and Czamanske 1994b; Czamanske et al. 1995; 1998). A common feature of the three intrusions is that they appear to have replaced the sedimentary sequence, rather than having been injected between the sedimentary layers (Czamanske et al. 1995 and references therein).

The layers of massive sulfides are localized in the lower part of the intrusions, largely in the country rocks and less frequently in the intrusion itself (Naldrett 2004; Sluzhenikin et al. 2014). Massive sulfides are often surrounded by a halo of veinlet-disseminated sulfides (Naldrett 2004 and references therein). Typical disseminated sulfides also occur in taxitic (mafic rocks with a very variable texture and composition containing xenoliths of gabbroic and country rocks) and picritic gabbrodolerites, and consist of isolated sulfide globules or aggregates, 0.5 to $4 \mathrm{~cm}$ across, and finer grained sulfides (3-20 vol.\%) dispersed among silicate minerals (Zen'ko and Czamanske 1994b; Czamanske et al. 1995). There is generally no contact between disseminated ores in taxitic and picritic gabbrodolerites and massive ores, massive sulfide can however be transgressive to the rocks of the intrusions and therefore to taxitic and picritic gabbrodolerites (Zen'ko and Czamanske 1994b; Czamanske et al. 1995).

A singularity of these intrusions is that the thickness of the massive sulfide deposits (up to $45 \mathrm{~m}$ ) is extremely large with respect to the total thickness $(70-350 \mathrm{~m})$ of the intrusions (Zen'ko and Czamanske 1994b; Czamanske et al. 1995; Naldrett 2004; Sluzhenikin et al. 2014). Zen'ko and Czamanske (1994b) estimated sulfide contents of 0.21, 2.82, and 7.06 wt.\% for Noril'sk 1, Talnakh, and Kharaelakh intrusions respectively, if only the intrusion is considered, or $0.17,0.92$ and 2.46 $w t . \%$, if the intrusion plus its peripheral sills are considered. This strong enrichment in sulfur of Noril'sk-Talnakh magmatic systems led several authors (e.g. Naldrett et al. 1992, 1996; Arndt et al. 2003, 2005; Li et al. 2003, $2009 a, b$; Naldrett 2004) to propose a contribution from sulfate-bearing host rocks, which are extremely common in the sedimentary sequence (Fig. 1c). Also the isotopic composition of $\mathrm{S}$ strongly suggests a contribution from country rocks: $\delta^{34} \mathrm{~S}$ of economic mineralized intrusions is variable but persistently positive in each intrusion (5-16\%; Grinenko 1985; Ripley et al. 2003; Li et al. 2003, 2009 a, b; Naldrett 2004 and references therein; Malitch et al. 2014), and markedly higher than the MORB values (e.g. $-0.91 \pm 0.50 \%$; Labidi et al. 2012). The $\delta^{34} S$ value of sulfide-bearing rocks is positively correlated to their S content (Li et al. 2009b), suggesting that heavy $S$ was ingested from crustal rocks $\left(\delta^{34} S\right.$ of anhydrite $18-22 \%$; Li et al $\left.2009 a, b\right)$. On the contrary, unmineralized intrusions have broader distributions of $\delta^{34} S$ from 0.5 to $16 \%$, with medians lower than $5 \%$ (Grinenko 1985), which rules out the possibility of an anomalously high $\delta^{34} \mathrm{~S}$ mantle signature. Sulfur degassing could increase the $\delta^{34} S$ of the magma, however it is unlikely to be the 
mechanism generating exceptional $\delta^{34} \mathrm{~S}$ values in ore-bearing intrusions, given that the majority of volcanic rocks in the area (certainly more degassed than intrusive rocks) have $\delta^{34} S$ values lower than $5 \%$ (Ripley et al. 2003). This corroborates the hypothesis of sulfate assimilation (Ripley et al. 2010), together with the coexistence of magmatic anhydrite with sulfide minerals having anomalously high $\delta^{34} \mathrm{~S}$ values in the Kharaelakh intrusion (Li et al. 2009a, b; Ripley et al. 2010). However, sub-economic intrusions with heavy isotopic compositions of $S$ also exist (Malitch et al. 2014), suggesting that sulfate assimilation is not the only mechanism playing a role in the formation of ore deposits.

Combined assimilation of evaporitic and organic matter-bearing rocks has been already suggested by different authors (Naldrett 2004; Arndt et al. 2005; Jugo and Lesher 2005; Li et al. 2009b; Ripley et al. 2010), but never exhaustively studied. Here we investigate the assimilation of both sulfate and organic compounds by means of experimental petrology and thermodynamic modeling: we show how they strongly control the redox state and the sulfur content of the magma and are therefore likely to play a fundamental role in the genesis of massive sulfide deposits.

\section{Materials and methods}

\subsection{Experimental strategy}

A picritic gabbro-dolerite from Noril'sk 1 intrusion (drill hole OM-1, depths $1005 \mathrm{~m}$ ) was used as starting material. This sample contains $11.4 \mathrm{wt} . \% \mathrm{MgO}$ and its overall composition is similar to that estimated by Arndt et al. (2003) of probable parental magmas of the ore-bearing intrusions. The rock was powdered and melted at $1600^{\circ} \mathrm{C}$ and atmospheric pressure for 2 hours, in order to obtain a homogeneous, volatile-free glass (composition in Table 1).

The experiments were conducted at $1200 \pm 2{ }^{\circ} \mathrm{C}$ in internally heated pressure vessels equipped with a rapid quenching device. Experimental pressures were $75 \pm 7 \mathrm{MPa}$, to match the pressures of emplacement of Noril'sk-Talnakh magmas (50-100 MPa; Krivolutskaya et al. 2001). Powdered starting glass was loaded into Pt capsules (internal diameter $2.5 \mathrm{~mm}$ ), together with powder or chips of coal or anhydrite (amounts in Table 2). Oxygen fugacity $\left(\mathrm{fO}_{2}\right)$ was controlled by varying the partial pressure of hydrogen in the vessel (Gaillard et al. 2001), and checked by redox sensor methods (Co$\mathrm{Pd}-\mathrm{CoO}, \mathrm{Ni}-\mathrm{Pd}$ - NiO; Taylor et al. 1992, details in Appendix A); the oxygen fugacities are listed in Table 2, expressed as logarithmic units relative to the Fayalite-Magnetite-Quartz buffer (FMQ).

A first series of experiments consisted of equilibrating the picritic melt at temperature, pressure and variable $\mathrm{fO}_{2}(<\mathrm{FMQ}-1$ to $\mathrm{FMQ}+1.5)$ in the presence of $\mathrm{S}\left(0.5-5\right.$ wt.\%) and $\mathrm{H}_{2} \mathrm{O}(0-2$ wt.\%). These experiments were undertaken to investigate how the $\mathrm{S}$ content of the melt at sulfide and sulfate saturation varies with $\mathrm{fO}_{2}$, in equilibrium conditions. A second series of interaction experiments 
coupled the picritic melt with coal from the Noril'sk region and blue anhydrite from the Oktyabrsky mine, characterized by big and pure crystals. These experiments lasted 10 to 160 minutes, in order to explore different aspects of the assimilation process. The objective of the shortest experiment (\#4) was to broadly explore the rates and reaction paths of the assimilation process, and not to retrieve quantitative information about them. In this experiment, we looked for the effect of coal or anhydrite assimilation on magma evolution, i.e. the occurrence of sulfide saturation and olivine crystallization, and the variations in the composition of the melt. The extremely short duration most likely prevented the $\mathrm{fO}_{2}$ within every capsule from equilibrating with that prevailing in the vessel (imposed by the amount of $\mathrm{H}_{2}$ loaded). Three capsules containing the picritic starting glass, 1 wt.\% $\mathrm{H}_{2} \mathrm{O}$ and $\sim 0.5$ wt.\% S were run simultaneously (\#4 in Table 2): one without coal or anhydrite (\#4.1), one with 11 wt.\% anhydrite (\#4.5), and one with 8 wt.\% coal (\#4.3). Differently, longer duration experiments (145-180 minutes; Table 2) aimed at equilibrating the redox conditions inside the capsules, in order to estimate them by the redox sensor method (see Appendix A). Experiment \#5.2 constrained the amount of $S$ dissolved in the melt at sulfate saturation. Finally experiment \#6.3 was designed to simulate the combined effect of anhydrite and coal assimilation on phase occurrence and composition: a hydrous, sulfate-saturated glass (\#5.2) was reheated at $1200 .^{\circ} \mathrm{C}$ and $\sim 80 \mathrm{MPa}$ in the presence of coal. Experimental conditions of every charge are listed in Table 2.

After the experiments, every capsule was verified to have remained sealed, then pierced and checked for the occurrence of a fluid phase (i.e. weight loss after piercing). The capsules were then cut half along their long axis, in order to preserve the geometry of the magma-coal or magmaanhydrite interaction, mounted in epoxy resin and polished.

\subsection{Analytical techniques}

Experimental products were observed by both optical and scanning electron microscopy (using a Tescan Mira 3XMU FEG-SEM and a ZEISS Merlin Compact FEG-SEM) to identify their phase assemblages, in particular the presence of sulfide droplets in the glass.

Major element compositions of the glasses and the minerals were analyzed with a Cameca SX Five electron microprobe (EMP). The following operating conditions were used for glasses, silicate minerals and Al-Fe oxides: $15 \mathrm{kV}$ accelerating voltage, $6 \mathrm{nA}$ beam current, $10 \mathrm{~s}$ counting time for all elements on each spot (except for S: $120 \mathrm{~s}$ ), $10 \mu \mathrm{m}$ spot size for glasses and a focused beam for minerals. Sodium was analyzed first to limit any loss. Sulfide droplets were analyzed using $20 \mathrm{kV}, 30$ 
$\mathrm{nA}, 10 \mathrm{~s}$ counting time and variable beam sizes depending on the size of the sulfide. X-ray images were also acquired at $15 \mathrm{Kv}$ and $100 \mathrm{nA}$, with a dwell time of $0.1 \mathrm{~s}$ and a step of $2 \mu \mathrm{m}$.

$\mathrm{H}_{2} \mathrm{O}$ contents in the quenched glasses were generally determined by the "difference method" (Devine et al. 1995), except for more oxidized, crystal-poor samples, for which transmission FTIR Spectroscopy was employed (details in the Appendix B).

$\mathrm{C}, \mathrm{N}, \mathrm{H}$, and $\mathrm{S}$ contents in the coal used as starting material were determined from the average of 16 analyses using a Flash 2000 Thermo Fisher Scientific C-H-N-S Elemental Analyzer (EA): 85.9 0.5 wt\% C, $3.0 \pm 0.2 w t \% H, 4.1 \pm 0.4 w t \% ~ N$, and $<0.5 w t \% S$.

\subsection{Thermodynamic modeling}

We used gas-melt thermodynamic calculations to simulate the assimilation of organic or sulfate compounds, and to investigate its effect on the redox conditions and the $S$ content of the magma. Our calculations take into account $\mathrm{S}-\mathrm{H}-\mathrm{O}-\mathrm{C}$ gaseous species at temperatures and pressures in equilibrium with mafic liquids (Gaillard et al. 2011; lacono-Marziano et al. 2012). This approach combines existing experimental studies performed on specific volatiles into a multi-component model, under the assumption of gas-melt equilibrium. The amounts of volatiles dissolved in the melt, as well as the gas composition are calculated using homogeneous (fluid-fluid) and heterogeneous (fluid-melt) thermodynamic equilibria (details in the Appendix C). In addition, here, we considered the variable speciation of sulfur in the melt according the equation of Jugo et al. (2010). This improvement allows us to run calculations over a broad range of oxygen fugacity (see Gaillard et al., 2015).

We assumed that the melt, prior to interaction with organic matter or anhydrite, has a total FeO content of $10.8 \mathrm{wt} . \%$, an oxygen fugacity close to the Fayalite-Magnetite-Quartz buffer (FMQ-0.5), as generally observed in basaltic magmas (Li and Lee 2005), and is sulfide saturated. The S content of the sulfide-saturated silicate melt at $1200{ }^{\circ} \mathrm{C}, 80 \mathrm{MPa}$, in the absence of a fluid phase, was fixed to 0.07 wt.\% (from the experimental results), while its $\mathrm{H}_{2} \mathrm{O}$ content was fixed to 1 wt.\% (to be consistent with most of the experimental data). We investigated the role of temperature $\left(1200-1350{ }^{\circ} \mathrm{C}\right)$, pressure (50-100 MPa), and initial gas content of the magma (between 0 and 2 wt.\%) in the assimilation process, in order to match all possible conditions of emplacement of Noril'sk, Talnakh and Kharaelakh intrusions. We also tested that varying the $\mathrm{H}_{2} \mathrm{O}$ content of the melt from 0.1 wt. \% to 2 wt.\%, in order to account for both the very low $\mathrm{H}_{2} \mathrm{O}$ contents measured in MORB glasses (Jambon, 
1994), and the extremely high $\mathrm{H}_{2} \mathrm{O}$ contents that could derive from the assimilation of water-rich sediments, had a negligible impact on the results of the modeling.

We imposed that the melt, prior to interaction with organic matter or anhydrite, is sulfide saturated i.e. sulfur fugacity in the melt equals sulfur fugacity at sulfide saturation calculated using the formulation of Mungall and Brenan (2014), which depends on temperature, pressure, oxygen fugacity and the total FeO content of the melt. During the assimilation process, we considered that the silicate melt was sulfide saturated whenever sulfur fugacity reached the value calculated using Mungall and Brenan (2014); the melt was otherwise considered sulfide under-saturated. This was in a good agreement with the independent experimental measurements of $S$ content at sulfide saturation.

Anhydrite assimilation was simulated by incremental addition of $\mathrm{SO}_{3}$ to the magma, up to $\sim 5$ wt.\%. Calculations were stopped when the $S$ content of the melt reached that of experimental sulfatesaturated samples $(0.9 \pm 0.1 \mathrm{wt}$.\% S). The assimilation of organic matter was simulated by the incremental addition of $\mathrm{CH}$, until sulfide saturation was reached. The organic compound $\mathrm{CH}$ is considered to be representative of mature organic matter (Charcosset and Nickel-Pepin-Donat 1990), which most likely interacted with Siberian magmas. To simplify our calculations, we ignored the possible presence of $\mathrm{O}$, or $\mathrm{S}$ in the organic matter. We also neglected olivine crystallization because the crystallization of 3-5 wt.\% olivine (shown by experiments at $1200{ }^{\circ} \mathrm{C}$ and $80 \mathrm{MPa}$ ) has a negligible effect on both the $S$ content and the $\mathrm{fO}_{2}$ of the melt.

\section{Results}

\subsection{Experimental results}

Figures 2 and 3 show experimental phase assemblages and Table 2 presents the most relevant characteristics of their compositions (complete analyses of experimental glasses and crystals are in the Supplementary Material). Samples equilibrated at different $\mathrm{fO}_{2}$ in the absence of coal or anhydrite and in the presence of $\mathrm{S}$ and $\mathrm{H}_{2} \mathrm{O}(\# 4.1, \# 6.2, \# 36.5, \# 52.1, \# 59.3, \# 44.2)$ consisted of glass, 3-5 wt.\% olivine and 1-3 wt.\% sulfide droplets, which represent a quenched sulfide melt (Fig. 2a, b, c). Figure 4 shows the sulfur content of these sulfide-saturated experimental melts as a function of $\mathrm{fO}_{2}$. The total $\mathrm{FeO}$ content of the melt $\left(\mathrm{FeO}^{*}\right)$ in these sulfide-saturated samples varies between 5.7 and 10.2 wt.\%, depending on both the amount of sulfide melt produced and the run duration, the latter controlling the Fe loss from the silicate melt to the Pt capsule. Despite this broad range of FeO* contents, the $\mathrm{S}$ contents of these melts show coherent variations as a function of $\mathrm{fO}_{2}$. The sample 
equilibrated at the lowest oxygen fugacity $(<F M Q-1)$ has a $S$ content of the melt $(0.07 \pm 0.02$ wt.\%) similar within the standard deviation to that of the sample equilibrated at FMQ-0.5 (Fig.4). This suggests a constant $\mathrm{S}$ content at sulfide saturation for $\mathrm{fO}_{2}$ lower than $\mathrm{FMQ}-0.5$. At higher $\mathrm{fO}_{2}$, the $\mathrm{S}$ content increases with $\mathrm{fO}_{2}$, as predicted by previous studies (e.g. Jugo et al. 2005; Jugo 2009). We compared our data with the values predicted by the multicomponent model of Jugo (2009) calibrated at $1300^{\circ} \mathrm{C}$ and $1 \mathrm{GPa}$ : we calculated the variation of the sulfur content at sulfide saturation as a function of oxygen fugacity (from equations 7 and 8 in Jugo 2009) for $S$ dissolved only as sulfide $=0.07$ wt.\% (Fig.4). Our data are systematically higher than predicted values, most likely due to the different experimental conditions and melt composition.

The experimental charges in which anhydrite was added (\#5.2 and \#4.5) are generally less crystallized (Fig. 2d, e, f), while those with added coal (\#4.3, \#6.3) are substantially more crystallized (Fig. 3) than the uncontaminated samples (\#4.1, \#6.2; Fig. 2a, b, c).

Experiment \#4, which was run for only 10 minutes, produced charges that are clearly less homogeneous in both their textures and their compositions (Fig. 2c, d, Fig. 3c, e, and Table 2) than those that equilibrated for more than 2 hours, especially for the $S$ content of the melt. This extremely short duration experiment has, however, the advantage that it offers better preserved magma-coal or magma-anhydrite interaction fronts: these samples therefore nicely illustrate how the assimilation of coal or anhydrite proceeds and affects magma evolution.

\subsubsection{Anhydrite assimilation}

Charge \#4.5 exemplifies how anhydrite dissolves in the magma, enriching it in $\mathrm{S}$ and $\mathrm{Ca}$ (Fig. 5b, e). Anhydrite dissolution follows convection paths, increasing the $S$ content of the melt by almost an order of magnitude within $500 \mu \mathrm{m}$ (Fig. 5e). On-going anhydrite dissolution generate melt zones rich in $\mathrm{S}$ and $\mathrm{Ca}$, in which both sulfide saturation (Fig. 5a, e) and olivine crystallization are inhibited (Fig. 2d, and Fig. 5a,f). As a consequence, the $\mathrm{SiO}_{2}$ content of the melt of these zone decreases (Fig. 5d), both by dilution (owing to $\mathrm{S}$ and $\mathrm{Ca}$ increase), and due to the suppression of olivine crystallization and sulfide segregation. In the rest of the sample, sulfide droplets and olivine are present, olivine being generally more forsteritic $(0.856<$ Fo $<0.880)$, than that in the uncontaminated sample \#4.1 $(0.851<$ Fo $<0.868)$. Forsterite contents of olivine crystallizing close to the anhydrite are slightly higher than those of olivine crystallizing farther away.

The experiment at higher $\mathrm{fO}_{2}$ produced a sulfate-saturated melt (\#5.2) with a $\mathrm{S}$ content substantially

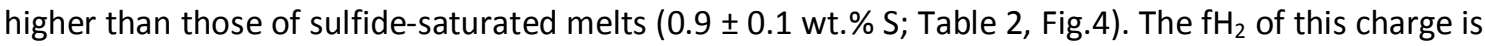


estimated to be equilibrated with the $\mathrm{fH}_{2}$ prevailing in the vessel, yielding a $\mathrm{fO}_{2}$ of $\mathrm{FMQ}+3.5( \pm 0.5)$ by the redox sensor method. Anhydrite was loaded in the form of powder, and recrystallized in roundish pockets at the rim (Fig.2e) and top of the capsule. This charge contains rare olivine, more forsteritic (0.896-0.908 Fo) than in charge \#4.5 (Table 2 ) and generally crystallizing far from anhydrite, and do not contain sulfide droplets (Figs. 2e, f). Al, Fe, Mg, Cr-oxides are frequently observed (Fig.2e, f), but their small sizes prevented precise analyses.

\subsubsection{Coal assimilation}

Charges \#6.3 and \#4.3 show that the effect of coal assimilation on the magma is to trigger plagioclase and clinopyroxene crystallization (elongated dark grey and small clear grey crystals, respectively, in Fig. 3). This is probably due to the lower amount of $\mathrm{H}_{2} \mathrm{O}$ dissolved in the melt (clearly lower than in charges with no assimilation or assimilation of anhydrite, despite the large scatter in the data; Supplementary Table 1). Sulfide segregation is strongly boosted in these samples (Fig.3). The larger amount of sulfides in charge \#6.3 (Fig. 3a, b) is likely due to the higher initial S content of the melt before interaction with coal ( $0.9 \pm 0.1$ wt.\%) than in charge \#4.3 (0.5 wt.\%; Fig.3c, e).

Most of the sulfide droplets are spatially associated with gas bubbles (Fig. 3), with the biggest bubbles containing the biggest droplets. Unlike anhydrite, which dissolves in the melt and does not substantially contribute to the formation of a fluid phase, coal contributes significantly to the fluid phase of the magma. This is corroborated by both the frequent occurrence of bubbles in the melt (Fig.3), and a significant weight loss of the capsule following piercing after the experiment (Table 2). Coal residues are nevertheless observed, most likely composed of graphite (Fig.3c).

The sulfur contents of the melts that assimilated coal are comparable to those of the most reduced equilibrium experiments ( $\mathrm{fO}_{2} \leq \mathrm{FMQ}-0.5$; Fig.4). The composition of the olivine is less forsteritic in charge \#4.3 (0.820 \pm 0.005 Fo), than in charge \#6.3 (0.906 \pm 0.004 Fo) probably reflecting the differentiation of the melt ( $\mathrm{MgO}$ in \#4.3 glass= 8.8 wt.\%).

\subsection{Modeling}

The thermodynamic modeling clarifies the effect of anhydrite or coal assimilation on the redox state of the magma, which is only qualitatively illustrated by the experiments. Figure 6 shows how anhydrite assimilation oxidizes the magma and at the same time increases its $\mathbf{S}$ content. We stopped the calculations when the $S$ content of the magma reached $~ 0.9$ wt.\%, which is the $S$ content at 
sulfate saturation shown by the experimental results at $1200^{\circ} \mathrm{C}$, and $80 \mathrm{MPa}$. This $\mathrm{S}$ content is likely to be higher at 1300 and $1350{ }^{\circ} \mathrm{C}$, however, because a strong temperature effect on the $\mathrm{S}$ content at sulfate saturation has been observed in differentiated magmas (Massotta and Keppler 2015).

The increase in oxygen fugacity due to sulfate addition is mainly controlled by the temperature and by the amount of fluid phase, while pressure has a negligible effect (Fig. 6a, b, c). These two parameters also affect to a larger extent the $S$ content of the melt (Fig. $6 d$, f). The lower the temperature and the initial gas content of the magma, the higher the $S$ content of the melt and the oxygen fugacity induced by the assimilation of a given amount of anhydrite. The initial gas content of the melt is an important parameter, because S strongly partitions in the fluid phase and therefore the more abundant the fluid phase the less abundant the $S$ in the melt (Fig. 6f). Calculations in Figure 6 simulate a closed system for the volatile phases, i.e. the fluid phase produced by the assimilation coexists with the melt. We also attempted to simulate open system conditions by removing the fluid phase formed at each calculation step: this tended to increase the $S$ content of the melt for a given amount of assimilated anhydrite, suggesting that volatile degassing from the magma during sulfate assimilation would reduce the amount of assimilation necessary to reach sulfate saturation in the magma. However, calculations were only possible for assimilation of less than 2 wt.\% anhydrite, preventing complete quantification of the degassing effect.

Sulfate assimilation also changes the speciation of $S$ in the silicate melt by modifying its redox conditions. In all simulations sulfide saturation is only maintained for few tenths of wt.\% of assimilated anhydrite (Fig. $6 \mathrm{~g}, \mathrm{~h}, \mathrm{i}$ ), because the proportion of the $\mathrm{S}^{2-}$ species rapidly decreases in the melt while that of $S^{6+}$ increases (Figs. 6j,k,l).

Figure 7a shows how the $\mathrm{S}$ content of the melt varies as a function of oxygen fugacity in response to anhydrite assimilation. The different curves represent calculations at different temperatures, pressures, and initial gas contents of the magma, and are compared to the experimental data defining the $\mathrm{S}$ content at sulfide and sulfate saturation at $1200{ }^{\circ} \mathrm{C}$ and $80 \mathrm{MPa}$. This comparison suggests that even in the most favorable conditions (a volatile-poor magma at $1200{ }^{\circ} \mathrm{C}$ and $100 \mathrm{MPa}$; black curve in Fig.7a) sulfide-saturation is maintained only for extremely low amounts of assimilated anhydrite (0.1-0.3 wt.\%), and is prevented for higher amounts. This is confirmed by the values of sulfur fugacity calculated for this assimilation path: (i) if less than $0.1-0.3 \mathrm{wt} \% \mathrm{CaSO}_{4}$ is assimilated, the calculated sulfur fugacity is higher than the sulfur fugacity at sulfide saturation computed following Mungall and Brenan (2014); (ii) if more than $0.3 \mathrm{wt} \% \mathrm{CaSO}_{4}$ is assimilated, the calculated sulfur fugacity is lower than that at sulfide saturation. Extreme contamination (> 3-5 wt.\% $\mathrm{CaSO}_{4}$, depending on the P-T-volatile conditions) brings the magma into the field where only sulfate species 
are stable in the melt. Under these conditions, sulfate saturation is possible provided that the sufficient amount of anhydrite is assimilated (Fig.7a).

The assimilation of organic matter ( $\mathrm{CH}$ in this study) has a dramatic effect on the redox state of the magma, and on the amount and composition of the gases coexisting with it (lacono-Marziano et al. 2012). Even low amounts of organic matter (0.5 wt.\%) can decrease the oxygen fugacity of the magma by several log units (Iacono-Marziano et al. 2012). Figure 7b illustrates the effect of $\mathrm{CH}$ addition to sulfate-saturated magmas on both the $\mathrm{fO}_{2}$ and $\mathrm{S}$ content in the melt (same $\mathrm{P}, \mathrm{T}, \mathrm{fluid}$ content conditions as in Fig. 7a). The $\mathrm{S}-\mathrm{fO}_{2}$ paths are very similar at given conditions in Figures $7 \mathrm{a}$ and $7 \mathrm{~b}$, but have opposite directions. $\mathrm{CH}$ addition decreases both the $\mathrm{fO}_{2}$ and the $\mathrm{S}$ content of the melt, leading back the magma towards sulfide-saturated conditions. In all cases calculations are stopped when sulfur fugacity reaches the predicted value at sulfide saturation (Mungall and Brenan 2014). Additional $\mathrm{CH}$ assimilation would decrease further the $\mathrm{fO}_{2}$ and the $\mathrm{S}$ content of the melt, following the sulfide-saturation curve. It is worth of note that the amount and the composition of the fluid phase coexisting with the magma are substantially different in the simulations presented in Figures 7a and 7b: the fluid phase is more abundant and S-rich when organic compounds are assimilated. This increase in the amount of fluid phase, coupled with a decrease in the $\mathrm{H}_{2} \mathrm{O}$ content of the melt, is predicted by the thermodynamic calculations and is also clearly observed in the coal assimilation experiments (Fig. 3 and Table 2). As for sulfate assimilation, the effect of organic matter assimilation increases with pressure: at higher pressure, the addition of a given amount of $\mathrm{CH}$ to the magma causes a greater decrease of both the $\mathrm{fO}_{2}$ and the $\mathrm{S}$ content of the melt. As already said, the presence of a fluid phase tends to extract S from the melt. Therefore the more abundant the fluid phase during the assimilation of organic compounds, the lower will be the $\mathrm{fO}_{2}$ and the $\mathrm{S}$ content of the magma.

\section{Discussion}

The experiments show that the assimilation of sulfate introduces $\mathrm{S}$ into the magma but inhibits sulfide saturation (Fig. 2d, e, f and Fig. 5). Anhydrite assimilation occurs via chemical dissolution in the sulfate-undersaturated silicate melt. No evidence of melting is observed; the silicate melt in contact with anhydrite is enriched in $\mathrm{Ca}$ and $\mathrm{S}$, and depleted in $\mathrm{SiO}_{2}$ by a dilution effect (Fig. 5b, d, e). Moreover, the inhibition of both sulfide saturation and olivine crystallization also contributes to deplete the melt in $\mathrm{SiO}_{2}$, while enriching it in $\mathrm{MgO}$ and $\mathrm{FeO}$ (Fig. 5c, f). The S content of the melt can increase by a factor of 10 with increasing $\mathrm{fO}_{2}$ (Table 2) to reach 0.9 wt.\% in the sulfate-saturated sample (\#5.2 with newly formed anhydrite). The thermodynamic calculations quantify this oxidizing 
effect and indicate that it is particularly important for low amounts of assimilation: the ingestion of few tenths of a percent of $\mathrm{CaSO}_{4}$ generally increases $\mathrm{fO}_{2}$ of one log unit, except in the presence of 2 wt.\% fluid phase (Fig. 6a, b, c). Our calculations also identify the most suitable circumstances under which sulfate assimilation can affect the $S$ content of the melt and the redox conditions. Sulfate assimilation is more effective at high pressure (100 MPa in this study), relatively low temperature (1200 ${ }^{\circ} \mathrm{C}$ in this study), and in the absence of fluid phase coexisting with the magma (Fig.6). Volatile degassing during sulfate assimilation therefore is likely to lead more rapidly to sulfate saturation in the magma (calculations not shown).

Olivine crystallization is clearly reduced by anhydrite assimilation (Fig. 2d, and Fig. 5a, f), but not completely inhibited (Fig. 2e, f). The inhibition of olivine crystallization could be due to $\mathrm{Ca}$ enrichment in the silicate melt, similarly to what is observed for the assimilation of carbonate rocks: the introduction of $\mathrm{Ca}$ in the melt destabilizes olivine and favors the crystallization of Ca-richer minerals, e.g. clinopyroxene (Iacono-Marziano et al. 2008). However, no Ca-rich phases are observed in the anhydrite bearing samples (Fig. $2 \mathrm{~d}$, e, f). On the contrary, the melt $\mathrm{H}_{2} \mathrm{O}$ contents of these samples (Supplementary Table 1) seem to be higher than those of anhydrite-free samples (see Appendix B). This could indicate $\mathrm{H}_{2} \mathrm{O}$ introduction in the melt by a partially hydrated anhydrite, yielding a decrease in olivine crystallization.

Coal assimilation has an opposite effect to anhydrite assimilation - it decreases the $\mathrm{H}_{2} \mathrm{O}$ and $\mathrm{S}$ contents of the melt (Table 2) and boosts both the crystallization of silicate minerals (olivine, plagioclase and clinopyroxene), and the segregation of sulfide globules (Fig. 3). The occurrence of hydrogen and carbon in the coal ensures dehydration of the melt, while an abundant fluid phase is produced, as predicted by thermodynamic calculations and documented by common bubbles associated with sulfide droplets in the experimental glasses (Fig. 3). Also in this case, the thermodynamic calculations support the reducing effects of the assimilation of organic matter suggested by the experiments (Fig. 7b). The amount of $\mathrm{CH}$ that needs to be assimilated to reach sulfide saturation is the lowest at high pressure and low temperature (100 MPa and $\left.1200^{\circ} \mathrm{C}\right)$, and in the absence of a fluid phase (Fig. 7b). All the modeling curves in Fig. $7 \mathrm{~b}$ meet the sulfide saturation curve described by the experimental data at shallow angles, probably indicating that only a small amount of sulfide melt is segregated over wide ranges in assimilated mass of organic matter. This is not appreciable in the experimental samples, where several wt.\% coal interacted with the magma (Table 2).

A reliable estimate of the rate of production of sulfide melt as a function of the rate of organic matter assimilation is still premature, in our opinion, as it is unclear whether the $\mathrm{S}$ necessary to 
segregate and grow the sulfide droplets comes from the fluid phase or the silicate melt. A close association between sulfide globules and vapor phase has been already documented in experimental samples by Mungall et al. (2015), who proposed that droplets of sulfide melt can attach to vapor bubbles and float through the magma. Natural samples from Noril'sk area also show textural evidence for sulfide flotation, suggesting $\mathrm{S}$ and $\mathrm{Ni}$ degassing during the crystallization of the orebearing intrusions (Le Vaillant et al., 2017). A complete model of S partitioning is required to simulate $S$ distribution between the fluid phase, the silicate melt and the sulfide liquid, and to estimate sulfide melt production in the magma due to the assimilation of organic compounds.

We discuss neither the thermal budget nor the kinetics of assimilation because our experiments are performed at a fixed temperature, i.e. the same temperature for magma and anhydrite or coal. However we stress that the experiments suggest extremely short timescales of both sulfate and coal assimilation, in agreement with the estimations of Robertson et al. (2015).

\subsection{Application to Noril'sk}

Both the extremely high sulfide contents of the ore bearing intrusions and the isotopic composition of S strongly suggest anhydrite assimilation in the Norils'k region (e.g. Arndt et al. 2003; Ripley et al. 2003; Li et al. 2003, 2009a,b; Naldrett 2004). The ${ }^{87} \mathrm{Sr} /{ }^{86} \mathrm{Sr}$ ratio of the intrusive rocks has also been considered to be evidence for evaporite contamination (Arndt et al. 2003). Assimilation of organic matter is needed to trigger sulfide saturation, which would be otherwise prevented by the oxidation of the melt during evaporite assimilation. Naldrett 2004 already proposed that near surface intrusions in the Noril'sk-Talnakh region assimilated both evaporite and coal measures, reducing the evaporite to segregate sulfides, as in "a natural smelter". The interaction with carbonaceous sediments is also clearly suggested by the stratigraphic position of the ore bearing intrusions (Fig.1c; Arndt et al. 2005).

Our experiments and thermodynamic calculations show that the combined assimilation of anhydrite and organic matter is a viable mechanism to reach sulfide saturation and produce massive sulfide deposits in the Noril'sk, Talnakh and Kharaelakh intrusions. A multi-level magma storage could have allowed the assimilation of Devonian sulfate-bearing rocks followed by the assimilation of organic matter-bearing rocks (either of the Tungusskaya series or of the Razvedochninsky formation), or the almost simultaneous assimilation of both. The ribbon-shape of the intrusions (Fig.1b) favors both large contact surfaces between the magma and the host rocks and the assimilation at different stratigraphic levels. The assimilation of the sedimentary (mainly carbonaceous) rocks would explain 
why a section of the sedimentary sequence appears to be missing in the three ore bearing intrusions and not in the barren ones (Czamanske et al. 1995 and references therein). In particular, Zen'ko and Czamanske (1994b) show that the base of the Kharaelakh intrusion and, to a lesser extent the distribution of the massive ore bodies, coincide with the boundary between the Kureysky and the Razvedochinsky formations (Figs. 4 and 9 in their paper), the former mainly consisting of marls, while the latter locally contains high concentrations of organic matter. This suggests that the stratigraphic contact between these two formations likely controlled the emplacement of the magma forming the Kharaelakh intrusion. Similarly, local sediment assimilation at the sites of the mineralized intrusions and replacement of sedimentary host rocks by cumulates and sulfide deposits have been proposed by Mungall for both the Noril'sk-Talnakh intrusions and the Expo Intrusive Suite in New Quebec, based on the modeling of the assimilation and crystallization processes (Mungall, 2014; Mungall, 2007).

Unlike other hypotheses about the formation of Noril'sk-Talnakh intrusions (see Naldrett 2004 for a review), the mechanism that we propose here does not require sulfide saturation in the magma entering the intrusion, in agreement with the absence of field evidence of sulfide-saturated feeder dykes, despite the numerous drill holes in the region.

The assimilation of anhydrite and organic matter most likely occurred under variable conditions in the different intrusions of the area, contributing to the formation of ore deposits, but also of subeconomic mineralization and barren intrusions. Indeed in the area only 3 out of more than 40 intrusions hosted in sedimentary rocks have massive sulfides. The composition of the magma is likely to be a critical parameter, because massive sulfides are found only in mafic ultramafic intrusions that are differentiated (generally from picritic to olivine-free or even quartz-bearing gabbrodolerites), while leucocratic intrusions are generally only weakly mineralized. However, several mafic-ultramafic intrusions in the Tungusska series contain only low-grade disseminated mineralization, but no massive ores (Naldrett 1992, 2004; Sluzhenikin et al. 2014). The extent of sulfate assimilation is likely to be a first fundamental limit to the amount of sulfides that can segregate. For instance, the ZubMarksheider intrusion is a differentiated mafic ultramafic intrusion that has the same stratigraphic position of the Kharaelakh intrusion, but presents in its lower part only small subeconomic sulfide disseminations with $\mathrm{Cu}, \mathrm{Ni}$, and PGE grades slightly lower than to those of Noril'sk type intrusions (Malitch et al. 2014). The sulfur isotopic composition of the sulfides of this intrusion is $0.4 \pm 1.6 \%$ (Malitch et al. 2014) suggesting no, or very few sulfate assimilation, which therefore did not supply enough $\mathrm{S}$ to produce massive ores. 
Even among the three ore-bearing intrusions, the amounts and compositions of disseminated and massive sulfides vary substantially (e.g. Czamanske et al. 1995; Naldrett 2004), although the textures and compositions of the intrusive rocks are essentially identical (Czamanske et al. 1995). In addition, lateral variations within individual intrusions are quite important (Naldrett 2004). Massive and disseminated sulfides of Kharaelakh, Talnakh, and Noril'sk 1 intrusions have extremely variable and heavy sulfur isotopic signatures: the Kharaelakh intrusion generally shows the heaviest and Noril'sk 1 the lightest compositions, with small difference between massive and disseminated sulfides (Grinenko 1985; Ripley et al. 2003; Li et al. 2003, 2009a,b; Naldrett 2004 and references therein; Malitch et al. 2014). The most recent survey (Malitch et al. 2014) indicates mean $\delta^{34} S$ of $12.6-12.8 \%$, for Kharaelakh, 10.9-11.0 \%, for Talnakh, and $9.2 \%$ for Norilsk 1 intrusions.

The $\mathrm{S}$ isotopic signature is strictly related to the amount of sulfate assimilated by the magma (Li et al. $2009 a, b)$, and it does not record the assimilation of organic matter that our study shows to be essential for effective sulfide segregation. For instance, the Northern and the Southern Maslovsky deposits in Noril'sk 1 intrusion are located in the Tungusska Formation and the basalts of the Ivakinsky Formation, respectively (Krivolutskaya et al. 2012). Sulfides are far less abundant and noneconomic in the Southern deposit, although their S isotopic signature (from 5.0 to $10.8 \%$; Krivolutskaya et al. 2012) suggest anhydrite assimilation. The magma that formed the Southern Maslovsky deposits is therefore likely to have less extensively interacted with coal-bearing sediments than the one that formed the Northern Maslovsky deposits. Another example attesting the crucial role of organic matter assimilation in the genesis of sulfide deposits is represented by the Fokinsky type intrusions, near horizontal sills hosted in the Devonian sediments, in which no sulfide mineralization has been detected (Czamanske et al. 1995; Sluzhenikin et al. 2014).

Estimation of the amounts of sulfate and organic matter assimilated is not straightforward, because these amounts are likely to be different from one intrusion to another and in different parts of the same intrusion. The isotopic signature of $S$ and the proportion of massive sulfides suggests that amount of assimilated sulfate is probably higher for the Kharaelakh intrusion than for the Talnakh intrusions, which is in turn higher than for the Noril'sk 1 intrusion. The Kharaelakh intrusion hosts a greater thickness of massive sulfide than the Talnakh intrusion, while massive ores in Noril'sk 1 intrusion occur only as small lenses, 2-5 m thick (Naldrett 2004). The occurrence of magmatic anhydrite in the picritic and taxitic rocks of the Kharaelakh intrusion (Li et al. 2009a,b) suggest that at least a portion of the mafic magma forming the intrusion was sulfate saturated. This would imply that the amount of anhydrite assimilated was locally higher than 3 wt\% (Fig. $6 \mathrm{~d}, \mathrm{e}, \mathrm{f}$ ). The $\delta^{34} \mathrm{~S}$ of the sulfide ores is extremely high (9-12.8\%; Li et al. 2009 b; Malitch et al. 2014), clearly corroborating the crustal provenance of the sulfur. However, the coexistence of the magmatic anhydrite with 
sulfides suggests an incomplete reduction of the oxidized magma (Ripley et al. 2010). The extremely high PGE, Ni, and Cu contents of the massive sulfides (Naldrett 2004) also indicate that not all the sulfur dissolved in the oxidized magma can have been reduced to sulfide. To account for these high metal contents, the upgrade of the sulfide melt is generally invoked, implying the exposure of the sulfide liquid to undepleted magma either passing through the intrusion to produce lava flows at surface, or deriving from multiple magma injections (Czamanske et al. 1995; Li et al. 2003; Naldrett 2004 and references therein; Barnes et al. 2016). Alternatively, the high metal contents could also derive from the accumulation of small discrete amounts of sulfide liquid to form a larger volume that segregates from the magma and infiltrates into the footwall rocks. The sulfide liquid is indeed extremely mobile due to its high density and low viscosity (Barnes et al. this volume). The production of small amounts of sulfide melt as a consequence of organic matter assimilation is suggested by the low angle at which the curves modeling $\mathrm{CH}$ assimilation cut the sulfide saturation one in Figure $7 \mathrm{~b}$. This mechanism would produce low sulfide supersaturations, which are the key to generate high ore metal tenors, like those observed in the Noril'sk-Talnakh region (Mungall, 2002; Mungall, 2014).

We therefore propose that disseminated and massive sulfides are produced by the intrusion of mantle-derived magma into the carbonaceous rocks of the Tunguska series or the Razvedochninsky formation. This mantle derived magma had already assimilated sulfate rocks and became oxidized and S-rich. The interaction with the organic matter triggers the crystallization of the magma and the partial reduction of the dissolved $S$ to segregate a sulfide melt. Disseminated sulfides in the taxitic and picritic gabbrodolerites could represent sulfide droplets transported in the magma, while the massive sulfides could derive from local accumulations of small fractions of sulfide melt, probably at the contact with the terrigeneous rocks.

The forsteritic content of the experimental olivine is generally higher than that of natural olivine (Czamanske et al. 1995), suggesting that the parental magma of the ore-bearing intrusions was less MgO-rich than picritic magmas. This has been already proposed based on the composition of the contact gabbrodolerite (e.g. Czamanske et al. 1995). Modeling results would be very similar for a basaltic magma, because the calculations only take into account the total $\mathrm{FeO}$ content of the silicate melt, and the $\mathrm{FeO}$ contents of $\mathrm{Mr}_{2}$ and $\mathrm{Mk}$ basalts, proposed to represent the parental magmas of ore-bearing intrusions (Czamanske et al. 1995), are comparable (11.4-11.8 wt.\% FeO; Naldrett 2004), to the value that we used for calculations (10.8 wt.\% FeO; Table 1 ). The only quantitative information retrieved from the experiments that could be different in basaltic melts is the $S$ content at sulfide/sulfate saturation: the trends shown in Figures 4 and 6 (d, e, f) would be probably shifted to slightly lower S contents (according to the experiments of Beermann et al. 2011 in mafic and ultramafic compositions). 
4.2 How to recognize that sulfate or organic matter assimilation occurred?

The assimilation of evaporite and organic matter can be difficult to recognize in the field, because it does not necessarily occur in-situ. Sulfate assimilation can take place during magma ascent, preferentially in the less steeply dipping sections of the feeding system, where thermo-mechanical erosion is more effective (Barnes et al. 2016); the S-rich or even sulfate-saturated magma can then rise to shallower stratigraphic levels, where the sedimentary sequence do not contain evaporites. This S-rich magma can probably be transported over long distances, given that evaporite assimilation prevents sulfide segregation and also seems to limit magma crystallization, therefore partially counterbalancing the cooling effect of the assimilation. A magma that assimilates organic matter can probably travel less extensively due to its higher crystallization. However, once an immiscible sulfide melt forms, due to its high density, it can separate from the magma and penetrate the footwall rocks, to depths of meters up to hundreds of meters (Barnes et al. 2016). Such downward infiltration into the host rocks has been clearly recognized in the Noril'sk-Talnakh intrusions (Naldrett 2004; Sluzhenikin et al. 2014; Barnes et al. 2016), suggesting that the oxidized magma could have interacted with carbonaceous sediments to form sulfide melts that reverse-flowed back down to the levels where the ore deposits accumulated. This obviously implies that massive sulfide deposits and, to a lesser extent, disseminated sulfide deposits are likely not to be in contact with the evaporitic and carbonaceous sediments that were assimilated by their parental magma. Similarly, Robertson et al. (2015) came to the conclusion that the source of crustal S can be distal relatively to the final emplacement site of the magma. Although droplets of sulfide melt can be transported in the magma, due to their attachment to vapor bubbles (Mungall et al., 2015), we stress that $S$ is probably more easily transported in oxidized, sulfide-undersaturated magmas, in which it is dissolved in the melt at high concentration levels.

The assimilation of anhydrite and organic matter is also difficult to recognize on the basis of the major or trace element compositions of the contaminated rocks. Both materials mostly supply volatiles and do not substantially change the chemical composition of the magma. The assimilation of anhydrite only slightly enriches the magma in $\mathrm{CaO}$ (1-2 wt.\% CaO; Table 2), which is not always easy to appreciate in an intrusive rock (it would probably favors clinopyroxene crystallization). The $S$ isotopic composition of the sulfides is probably the clearest marker of the assimilation of crustal $\mathrm{S}$ (Ripley and Li 2003). There are no distinct markers of the assimilation of organic matter, its main effects being to dry and reduce the magma. Only the occurrence of magmatic (Iacono-Marziano et al. 
2012) or residual graphite (Fig. 3c, e) is a strong indicator of the interaction of the magma with carbonaceous rocks. However, organic matter is mainly composed of volatile elements $(\mathrm{C}, \mathrm{H}, \mathrm{N})$ and during interaction with the magma it produces an abundant fluid phase coexisting with, or escaping from, the magma. The role of volatiles is a poorly understood and commonly neglected aspect of magmatic sulfide ore genesis in mafic intrusions (Barnes et al. 2016). Mineralized intrusions of the Noril'sk area are surrounded by an intense metamorphic and metasomatic aureole as thick as the intrusion itself (up to $450 \mathrm{~m}$ ) and more developed above the intrusion than beneath it (Genkin et al. 1981; Czamanske et al. 1995; Naldrett 2004). This observation, which suggests an important role of fluids, has lead several authors to propose that sulfide ores could be of hydrothermal-metasomatic origin (Pokrovskii et al. 2005 and references therein). The aureoles surrounding weakly mineralized intrusions are far less thick (15-80 m), and only a few meters thick in barren intrusions (Pokrovskii et al. 2005). This feature of Noril'sk type intrusion, which has always been difficult to explain without invoking an exceptionally elevated thermal regime (Czamanske et al. 1995), is probably one of the clearest evidence of the assimilation of organic matter. Moreover, calcite mineralization in the metasomatic aureoles of Noril'sk 1 intrusion have strongly negative $\delta^{13} \mathrm{C}$ reaching $-19.4 \%$ PDB, which indicates an organic source of carbon (Pokrovskii et al. 2005).

There is further evidence for abundant fluids in the ore-bearing intrusions: the intrusive breccia in some localities at the roof of the intrusions, up to $25 \mathrm{~m}$ thick (Naldrett 2004), and the frequent explosive events in the flood-basalt sequence (Czamanske et al. 1995). But the clearest indication of the involvement of volatiles is the occurrence of taxitic gabbrodolerites, very complex rocks with variable composition (leucocratic to melanocratic) containing fine-grained and pegmatitic areas, with some signatures of a magmatic breccias (inclusions of other gabbroic and also country rocks; Naldrett et al. 1992; Czamanske et al. 1995). These characteristics all point to high volatile contents coexisting with magmas that initially were dry (Barnes et al. 2016).

Finally, chemical and isotopic heterogeneities are typical markers of assimilation processes, because assimilation is a local process (Iacono-Marziano et al. 2008). In the Noril'sk area chemical, isotopic and even textural heterogeneities are particularly strong in both intrusive rocks and ore deposits (Naldrett 2004 and references therein).

\section{$\underline{\text { 5. Conclusions }}$}

Why do large massive sulfide ore deposits occur in the Noril'sk-Talnakh region? 
- Mafic, ultramafic magmas produced in mantle plumes contain high contents of $\mathrm{Ni}, \mathrm{Cu}$ and PGE because they are produced by high degrees of mantle melting that allowed total dissolution of the Ni-Cu-PGE-bearing immiscible sulfide liquid into the magma (Arndt et al. 2005; Barnes et al. 2016).

- In the Noril'sk-Talnakh region (as in the Maymecha-Kotuy basin), magma intrusion rates are higher than in the remainder of the Siberian Trap (Naldrett 2004 and references therein).

- In the Noril'sk-Talnakh region the evaporite-rich sedimentary sequences are exceptionally thick (Naldrett 2004 and references therein), much thicker than in the rest of the Siberian platform (while the stratigraphic sequence of the Maymecha-Kotuy basin do not contain evaporites). This point, coupled to the exceptional magma intrusion rate, allows high degrees of assimilation of anhydrite, which probably are unlikely elsewhere in the Siberian platform. Here we provide experimental and thermodynamic constraints clarifying reaction paths and mechanisms of this assimilation process.

- Coal is almost ubiquitous in the Tunguska basin, with important thickness (Czamanske et al. 1998). Native iron bearing intrusions in the Maimecha, Khininda, Khungtukun and Ozernaya Mountain intrusions, and in the Dzhaltul igneous complex (less than $150 \mathrm{~km}$ south of Noril'sk, Fig.1a) indeed indicate that assimilation of organic matter by Siberian magmas is a common process (Ryabov and Lapkovsky 2010; lacono-Marziano et al. 2012). If the magma is S-poor (no evaporites in the sedimentary sequence), the reduction of the magma by the organic matter produces native iron, instead of sulfide segregation. The calculated amounts of organic matter necessary to reach sulfide saturation in the magma are similar to those calculated to reach native iron saturation (Iacono-Marziano et al. 2012).

We finally recall that the Noril'sk-Talnakh ore deposits have been discovered and exploited only because of tectonic uplift of the local area followed by erosion of more than $1 \mathrm{~km}$ of basalts (Barnes et al. 2016). We therefore conclude that very specific conditions are necessary to produce and bring to the surface Noril'sk type ores, probably making these deposits unique in the world.

\section{Acknowledgements}

This work has been supported by the French agency for research (ANR projects \#12-JS06-0009-01 and \#2010 BLAN62101) and the European Research Council (ERC project \#279790). We thank Nadezhda A. Krivolutskaya, Sergey F. Sluzhenikin, and the leaders of the Noril'sk field trip of the $12^{\text {th }}$ 
International Platinum Symposium for the useful discussions and their valuable help in sampling the starting materials of this study. We also thank Margaux Le Vaillant and Stephen J. Barnes for their precious insights about magmatic sulfide ore formation, and Patricia Benoist-Julliot and Marielle Hatton for their assistance with the SEM and the Elemental Analyzer. The present manuscript has been sensibly improved by the careful and constructive reviews of Chusi Li and James E. Mungall.

\section{$\underline{\text { References }}$}

Arndt, N.T., Czamanske, G.K., Walker, R.J., Chauvel, C., Fedorenko, V.A., 2003. Geochemistry and origin of the intrusive hosts of the Noril'sk-Talnakh $\mathrm{Cu}-\mathrm{Ni}-\mathrm{PGE}$ sulfide deposits. Econ. Geol. Bull. Soc. Econ. Geol. 98, 495-515.

Arndt, N.T., Lesher, C.M., Czamanske, G.K., 2005. Mantle derived magmas and magmatic Ni-Cu-PGE deposits. Econ. Geol. 100th Anniversary Volume, 5-24.

Barnes, S.J., Cruden, A.R., Arndt, N.T., Saumur, B.M., 2016. The mineral system approach applied to magmatic Ni-Cu-PGE sulphide deposits. Ore Geol. Rev. 76, 296-316.

Barnes, S.J., Le Vaillant, M.,Lightfoot, P., this volume. Textural development in sulfide-matrix ore breccias and associated rocks in the Voisey's Bay Ni-Cu-Co deposit, Labrador.

Beermann, O., Botcharnikov, R.E., Holtz, F., Diedrich, O., Nowak, M., 2011. Temperature dependence of sulfide and sulfate solubility in olivine-saturated basaltic magmas. Geochim. Cosmochim. Acta 75, 7612-7631.

Botcharnikov, R.E., Almeev, R.R., Koepke, J., Holtz, F., 2008. Phase relations and liquid lines of descent in hydrous ferrobasalt - Implications for the Skaergaard Intrusion and Columbia River Flood Basalts. J. Pet. 49, 1687-1727.

Charcosset, H., Nickel-Pepin-Donat, B., 1990. Advanced methodologies in coal characterization. Elsevier Amsterdam, $442 \mathrm{p}$.

Czamanske, G.K., Zen'ko, K.E., Fedorenko, V., Calk, L.C., Budahn, J.R., Bullock, J.H.J., Fries, T.L., King, B.S., Siems, D.F., 1995. Petrographic and geochemical characterization of ore-bearing intrusions of the Noril'sk Type, Siberia; with discussion of their origin. Resour. Geol. Special Issue 18, 1-48.

Czamanske, G.K., Gurevitch, A.B., Fedorenko, V., Simonov, O., 1998. Demise of the Siberian Plume: paleogeographic and paleotectonic reconstruction from the prevolcanic and volcanic record, NorthCentral Siberia. Int. Geol. Rev. 40, 95-115.

Devine, J.D., Gardner, J.E., Brach, H.P., Layne, G.D., Rutherford, M.J., 1995. Comparison of microanalytical methods for estimation of $\mathrm{H} 2 \mathrm{O}$ content of silicic volcanic glasses. Am. Mineral. 80, 319-328. 
Fedorenko V.A. 1994. Evolution of magmatism as reflected in the volcanic sequence of the Noril'sk region. In Lightfoot, P.C. and Naldrett, A.J, eds: Proceedings of the Sudbury-Noril'sk Symposium, Special Publ. 5, Geological Survey, Ontario, 171-184.

Fine, G., Stolper, E., 1986. Dissolved carbon-dioxide in basaltic glasses - concentrations and speciations. Earth Planet. Sci. Lett. 76, 263-278.

Fortin, M-A. Riddle, J., Desjardins-Langlais, Y., Baker, D., 2015. The effect of $\mathrm{H} 2 \mathrm{O}$ on the sulfur concentration at sulfide saturation (SCSS) in natural melts. Geochim. Cosmochim. Acta 160, 100-116.

Gaillard, F., Scaillet, B., Pichavant, M., Bény, J.M., 2001. The effect of water and $\mathrm{fO}_{2}$ on the ferricferrous ratio of silicic melts. Chem. Geol. 174, 255-273.

Gaillard, F., Scaillet, B., Arndt, N.T., 2011. Atmospheric oxygenation caused by a change in volcanic degassing pressure. Nature 478, 229-232.

Gaillard, F., Scaillet, B., Pichavant, M., lacono-Marziano, G., 2015. The redox geodynamics linking basalts and their mantle sources through space and time. Chem. Geol. 418, 217-233.

Genkin, A.D., Distler V.V., Gladyshev, G.D., Filimonova, A.A., Evstigneeva, T.L., Kovalenkor, V.A., Laputina, I.P., Smirnov, A.V., Grokhovskaya, T.L., 1981. Sulphide copper-nickel ores of the Noril'sk deposits. Nauka. Moscow, 234 p. (in Russian).

Grinenko, L.N., 1985. Sources of sulfur of the nickeliferous and barren gabbro-dolerite intrusions of the northwest Siberian platform. Int. Geol. Rev. 28, 695-708.

Iacono-Marziano, G., Gaillard, F., Pichavant, M., 2008. Limestone assimilation by basaltic magmas: an experimental re-assessment and application to Italian volcanoes. Contrib. Mineral. Petrol. 155, 719738.

Holloway, J.R., 1987. Igneous fluids. Rev. Mineral. Geochem. 17, 211-233.

Iacono-Marziano G., Schmidt B.C., Dolfi D., 2007. Equilibrium and disequilibrium degassing of a phonolitic melt (Vesuvius AD 79 "white pumice") simulated by decompression experiments. Journal of Volcanology and Geothermal Research 161, 151-164.

Iacono-Marziano G., Gaillard F., Pichavant M., 2008. Limestone assimilation by basaltic magmas: an experimental re-assessment and application to Italian volcanoes. Contrib. Mineral. Petrol. 155, 719738.

lacono-Marziano, G., Gaillard, F., Scaillet, B., Polozov, A.G., Marecal, V., Pirre, M., Arndt, N., 2012. Extremely reducing conditions reached during basaltic intrusion in organic matter-bearing sediments, Earth Planet. Sci. Lett. 357-358, 319-326.

lacono-Marziano G., Morizet Y., Le Trong E., Gaillard F., 2012 b. New experimental data and semiempirical parametrization of $\mathrm{H}_{2} \mathrm{O}-\mathrm{CO}_{2}$ solubility in mafic melts. Geochimica et Cosmochimica Acta 97, $1-23$.

Jambon, A., 1994. Earth degassing and large-scale geochemical cycling of volatile elements. Reviews in Mineralogy 30, 479-509. 
Jugo, P.J., and Lesher, C.M., 2005. Redox changes caused by evaporate and carbon assimilation at Noril'sk and their role in sulfide precipitation [abs.]. Geological Society of America Abstracts with Programs 39, 360.

Jugo, P.J., Luth, R.W., and Richards, J.P., 2005. An experimental study of the sulfur content in basaltic melts saturated with immiscible sulfide or sulfate liquids at $1300^{\circ} \mathrm{C}$ and $1.0 \mathrm{GPa}$. J. Pet. $46,783-798$.

Jugo, P.J., 2009. Sulfur content at sulfide saturation in oxidized magmas. Geology 37, 415-418.

Jugo, P.J., Wilke, M., Botcharnikov, R.E., 2010. Sulfur K-edge XANES analysis of natural and synthetic basaltic glasses: implications for $\mathrm{S}$ speciation and $\mathrm{S}$ content as a function of oxygen fugacity. Geochim. Cosmochim. Acta 74, 5926-5938.

Kamo, S.L., Czamanske, G.K., Krogh, T.E., 1996. A minimum U-Pb age for Siberian flood-basalt volcanism. Geochimica et Cosmochimica Acta 60, 3505-3511.

Kamo, S.L., Czamanske, G.K., Amelin, Y., Fedorenko, V.A., Davis, D.W., Trofimov, V.R., 2003. Rapid eruption of Siberian flood-volcanic rocks and evidence for coincidence with the Permian-Triassic boundary and mass extinction at $251 \mathrm{Ma}$. Earth Planet. Sci. Lett. 214, 75-91.

Kress, V.C., Carmichael, I.S.E., 1991. The compressibility of silicate liquids containing Fe2O3 and the effect of composition, temperature, oxygen fugacity and pressure on their redox states. Contrib. Mineral. Pet. 108, 82-92.

Krivolutskaya, N.A., Ariskin, A.A., Sluzhenikin, S.F., Turovtsev, D.M., 2001. Geochemical thermometry of rocks of the Talnkh intrusion: assessment of the melt composition and the crystallinity of the parental magma. Petrology 9, 389-414.

Krivolutskaya, N.A., Sobolev, A.V., Snisar, S.G., Gongalskiy, B.I., Hauff, B., Kuzmin, D.V., Tushentsova, I.N., Svirskaya, N.M., Kononkova, N.N., Schlychkova, T.B., 2012. Mineralogy, geochemistry and stratigraphy of the Maslovsky Pt-Cu-Ni sulfide deposit, Noril'sk Region, Russia: Implications for relationship of ore-bearing intrusions and lavas. Mineralium Deposita 47, 69-88.

Labidi, J., Cartigny, P., Birck, J.L., Assayag, N., Bourrand, J.J., 2012. Determination of multiple sulfur isotopes in glasses: a reappraisal of the MORB $\delta^{34}$ S. Chem. Geol. 334, 189-198.

Le Vaillant M., Barnes S.J., Mungall J.E., Mungall E.L., 2017. Role of degassing of the Noril'sk nickel deposits in the Permian-Triassic mass extinction event. Proc. Nat. Acad. Sci. USA 114, 2485-2490.

Li, C., Ripley, E.M., and Naldrett, A.J., 2003. Compositional variations of olivine and sulfur isotopes in the Noril'sk and Talnakh intrusions, Siberia: Implications for ore-forming processes in dynamic magma conduits. Econ. Geol. 98, 69-86.

Li, C., Ripley, E.M., Naldrett, A.J., Schmitt, A.K., and Moore, C.H., 2009a. Magmatic anhydrite-sulfide assemblages in the plumbing system of the Siberian traps. Geology 37, 259-262.

Li, C., Ripley, E.M., Naldrett, A.J., 2009b. A new genetic model for the giant Ni-Cu-PGE sulfide deposits associated with the Siberian flood basalts. Econ. Geol. Bull. Soc. Econ. Geol. 104, 291-301.

Li, Z.X.A., Lee, C.T.A., 2005. The constancy of upper mantle $\mathrm{fO}(2)$ through time inferred from V/Sc ratios in basalt. Earth Planet. Sci. Lett. 228, 483-493. 
Malich, N.S., Tazihin, N.N., Tuganova, E.V., Bunzen, E.A., Kulikova, N.G., Safonova, Ivapoa, V.B., Baskov, E.A., Galabala, P.O., Gavrikov, S.I., Golovanova, M.P., Gogina, N.I., Gorshkova, N.I., Grozdilov, A.L., Gromova, A.I., Egorov, L.S., Ivanova, A.M., Isaeva, L.L., Kljuchanskyi, N.G., Kolobova, N.I., Kutejnikov, E.S., Leonov, B.N., Ledneva, V.P., Mironjuk, E.P., Mihajlov, M.V., Mishnin, V.M., Stavtsev, A.L., Stulov, A.T., Shahotko, L.I., Schtein, L.F., Tsekhomskyi, A.M., Yanova, E.N., 1974. Map of geological formations of the Siberian platform cover (1:1 500 000). In: Malich, N.S. (Ed.), All-Union Research Geologic Institute (VSEGEI), Leningrad.

Malitch, K.N., Latypov, R.M., Badanina, I.Yu., Sluzhenikin, S.F., 2014. Insights into ore genesis of NiCU-PGE sulfide deposits of the Noril'sk Province (Russia): evidence from copper and sulfur isotopes. Lithos 204, 172-187.

Masotta, M., Keppler, H., 2015. Anhydrite solubility in differentiated arc magmas. Geochim. Cosmochim. Acta 158, 79-102.

Mavrogenes, J.A., O'Neill, H.S.C., 1999. The relative effect of pressure, temperature and oxygen fugacity on the solubility of sulphide in mafic magmas. Geochim. Cosmochim. Acta 63, 1173-1180.

Morizet, Y., Paris, M., Gaillard, F., Scaillet, B., 2010. C-O-H fluid solubility in haplobasalt under reducing conditions: an experimental study. Chem. Geol. 279, 1-16.

Mungall, J.E., 2002. Kinetic controls on the partitioning of trace elements between silicate and sulfide liquids. J. Pet. 43, 749-768.

Mungall, J.E., 2007. Crustal contamination of picritic magmas during transport through dikes: the Expo Intrusive Suite, Cape Smith Fold Belt, New Quebec. J. Pet. 48, 1021-1039.

Mungall, J.E., 2014. Geochemistry of magmatic ore deposits. Treatise on Geochemistry: Geochemistry of Mineral Deposits (Elsevier, Amsterdam) 13, 195-218.

Mungall, J.E., Brenan, J.M., 2014. Partitioning of platinum-group elements and Au between sulfide liquid and basalt and the origins of mantle-crust fractionation of the chalcophile elements. Geochim. Cosmochim. Acta 125, 265-289.

Mungall, J.E., Brenan, J.M., Godel, B., Barnes, S.J., and Gailard, F., 2015. Transport of S, Cu and Au in magmas by flotation of sulphide melt on vapour bubbles. Nature Geoscience, 8, 216-219.

Naldrett, A.J., Lightfoot, P.C., Fedorenko, V., Doherty, W., Gorbachev, N.S., 1992. Geology and geochemistry of intrusions and flood basalts of the Noril'sk region, USSR, with implications for the origin of the Ni-Cu ores. Econ. Geol. 87, 975-1004.

Naldrett, A.J., Fedorenko, V.A., Lightfoot, P.C., Kunilov, V.I., Gorbachev, N.S., Doherty, W., and Johan, Z., 1996. Controls on the composition of Ni-Cu sulfide deposits as illustrated by those at Noril'sk, Siberia. Econ. Geol. 91, 751-773.

Naldrett, A.J., 2004. Magmatic Sulfide Deposits: Geology, Geochemistry and Exploration. Springer, Heidelberg.

Pan, V., Holloway, J.R., Hervig, R.L., 1991. The pressure and temperaturedependence of carbon dioxide solubility in tholeiitic basalt melts. Geochim. Cosmochim. Acta 55, 1587-1595. 
Pokrovskii, B.G., Sluzhenikin, S.F., Krivolutskaya, N.A., 2005. Interaction conditions of Noril'sk Trap Intrusions with their host rocks: isotopic (O, H, and C) evidence. Petrology 13, 49-72.

Pownceby, M.I., O'Neill, H.S.C., 1994. Thermodynamic data from redox reactions at high temperature. IV. Calibration of the $\mathrm{Re}-\mathrm{ReO}_{2}$ oxygen buffer from EMF and $\mathrm{NiO}+\mathrm{Ni}-\mathrm{Pd}$ redox sensor measurements. Contrib. Mineral. Petrol. 118, 130-137.

Rempel, G.G., 1994. Regional geophysics at Noril'sk. In Lightfoot, P.C. and Naldrett, A.J, eds: Proceedings of the Sudbury-Noril'sk Symposium, Special Publ. 5, Geological Survey, Ontario, 147-160.

Ripley, E.M., Li, C.S., 2003. Sulfur isotope exchange and metal enrichment in the formation of magmatic Cu-Ni-(PGE) deposits. Econ. Geol. Bull. Soc. Econ. Geol. 98, 635-641.

Ripley, E.M., Lightfoot, P.C., Li, C., Elswick, E.R., 2003. Sulfur isotopic studies of continental flood basalts in the Noril'sk region: implications for the association between lavas and ore-bearing intrusions. Geochim. Cosmochim. Acta 67, 2805-2817.

Ripley, E.M., Li, C., Moore, C.H., and Schmitt, A.K., 2010. Micro-scale S isotope studies of the Kharaelakh intrusion, Noril'sk region, Siberia: Constraints on the genesis of coexisting anhydrite and sulfide minerals. Geochim. Cosmochim. Acta 74, 634-644.

Robertson, J.C., Ripley, E.M., Barnes, S.J., Li, C., 2015. Sulfur Liberation From Country Rocks and Incorporation in Mafic Magmas. Econ. Geol. 110, 1111-1123.

Ryabov, V.V., Lapkovsky, A.A., 2010. Native iron (-platinum) ores from the Siberian Platform trap intrusions. Austral. J. Earth Sci. 57, 707-736.

Shi, P.F., Saxena, S.K., 1992. Thermodynamic modelling of the C-H-O-S fluid system. Am. Mineral. 77, 1038-1049.

Simonov, O.N., Lul'ko, V.A., Amosov, Yu.N., Salov, V.M., 1994. Geological structure of the Noril'sk region. In Lightfoot, P.C. and Naldrett, A.J, eds: Proceedings of the Sudbury-Noril'sk Symposium, Special Publ. 5, Geological Survey, Ontario, 171-184.

Sluzhenikin, S.F., Krivolutskaya, N.A., Rad'ko, V.,Malitch, K.N., Distler, V.V., Fedorenko, V.A., 2014. Ultramafic-Mafic Intrusions, Volcanic Rocks and PGE-Cu-Ni Sulfide Deposits of the Noril'sk Province, Polar Siberia, Field Trip Guidebook. Institute of Geology of Ore Deposits, Petrography, Mineralogy and Geochemistry, Yekaterinburg, Russia.

Symonds, R.B., Reed, M.H., 1993. Calculation of multicomponent chemical equilibria in gas-solidliquid systems: calculation methods, thermochemical data and applications to studies of hightemperature volcanic gases with examples from Mount St Helens. Am. J. Sci. 293, 758-864.

Taylor, J.R., Wall, V.,J., Pownceby, M.I., 1992. The calibration and application of accurate redox sensors. Am. Mineral. 77, 284-295.

Zharkov, M.A., 1984. Paleozoic Salt Bearing Formations of the World. Springer-Verlag, Berlin, Heidelberg, New York \& Tokyo.

Zen'ko, T.E., and Czamanske, G.K., 1994a. Spatial and petrologic aspects of the intrusions of the Noril'sk and Talnakh ore junctions. In Lightfoot, P.C. and Naldrett, A.J, eds: Proceedings of the Sudbury-Noril'sk Symposium, Special Publ. 5, Geological Survey, Ontario, 263-281. 
Zen'ko, T.E., and Czamanske, G.K., 1994b. Tectonic controls on ore-bearing intrusions of the Talnakh ore junction: Position, morphology and ore distribution. Int. Geol. Rev. 36, 1033-1057.

\section{APPENDIX A: Redox sensors}

The redox conditions for each capsule were monitored using the Co-Pd-O solid sensor method (Taylor et al. 1992). The solid sensor consisted of two pellets of CoPd metal mixtures (each with different $\mathrm{Co} / \mathrm{Pd}$ ratio) and $\mathrm{CoO}$, placed in a Pt capsule in the presence of excess $\mathrm{H}_{2} \mathrm{O}$, and run at the same time of the samples, but for a longer duration (3-4 days, in order to equilibrate). The $\mathrm{fO}_{2}$ of the sensor was determined from the composition of its metallic phases, following Pownceby and O'Neill (1994), and the $\mathrm{fO}_{2}$ of each charge then calculated following Botcharnikov et al. (2008) from the activity of $\mathrm{H}_{2} \mathrm{O}$ estimated for every charge using the model of lacono-Marziano et al. (2012b).

APPENDIX B: Determination of $\mathrm{H}_{2} \mathrm{O}$ contents dissolved in the experimental glasses

$\mathrm{H}_{2} \mathrm{O}$ contents in glasses were determined by the "difference method" (Devine et al. 1995) from the totals of the electron microprobe analyses. The method was calibrated using 6 standard glasses of picritic composition with known $\mathrm{H}_{2} \mathrm{O}$ contents between 1.7 and 4.7 wt.\%. The $\mathrm{H}_{2} \mathrm{O}$ content of the 6 glasses were analyzed by transmission FTIR spectroscopy on doubly polished glass chips using an IR Continu $\mathrm{mm}$ microscope coupled to à Nicolet 6700 spectrometer. Absorption spectra were acquired for each sample in the range 1000-6000 cm${ }^{-1}$ with 128 scans and a resolution of $4 \mathrm{~cm}^{-1}$, using a Globar internal IR source, a $\mathrm{KBr}$ beamsplitter, and a MCT/A detector. For each sample 6-10 spots were analyzed to verify the homogeneity of the $\mathrm{H}_{2} \mathrm{O}$ content in the glass. Water was calculated from the absorbance of the fundamental $\mathrm{OH}^{-}$stretching vibration at about $3530 \mathrm{~cm}^{-1}$, using the LambertBeer law and the extinction coefficients determined by Fine and Stolper (1986) for a basaltic composition.

The accuracy of the by difference method can be lower than $0.5 \mathrm{wt} . \%$, when it is carefully calibrated with glasses of similar composition and similar water contents (Iacono-Marziano et al. 2007). However, in this study the composition of the experimental glasses can vary from the composition of the standard glasses. Moreover, both crystallization and the variations in the oxygen fugacity affect the $\mathrm{Fe}^{3+} / \mathrm{FeO}^{*}$ ratio of the melt and therefore the EMP total of the experimental glasses. We analyzed the $\mathrm{H}_{2} \mathrm{O}$ contents of the more oxidized and less crystallized glass (\#5.2) by transmission FTIR spectroscopy, obtaining a $\mathrm{H}_{2} \mathrm{O}$ content 0.8 wt.\% lower than that estimated by EMP (see Supplementary Table S1). Therefore, we estimate that the $\mathrm{H}_{2} \mathrm{O}$ content of sample \#4.5 is probably also overestimated by EMP.

APPENDIX C: Thermodynamic modeling 
The gas composition was calculated following Gaillard et al. (2011). This methodological approach is long known as the "Equilibrium constants and mass balance method" Holloway 1987) to calculate equilibria in the $\mathrm{C}-\mathrm{O}-\mathrm{H}$ system, briefly recalled below. The mole fractions of the different gas species were calculated from the thermodynamic constants of the following equilibria at P and T (after Shi and Saxena 1992).

$$
\begin{aligned}
& \mathrm{C}^{\text {[graphite] }}+\mathrm{O}_{2}=\mathrm{CO}_{2}{ }^{\text {[fluid] }} \\
& \mathrm{CO}^{\text {[fluid] }}+1 / 2 \mathrm{O}_{2}=\mathrm{CO}_{2}{ }^{\text {ffluid] }} \\
& \mathrm{H}_{2}{ }^{\text {[fluid] }}+1 / 2 \mathrm{O}_{2}=\mathrm{H}_{2} \mathrm{O}^{\text {[fluid] }} \\
& \mathrm{CH}_{4}{ }^{\text {[fluid] }}+2 \mathrm{O}_{2}=\mathrm{CO}_{2}{ }^{\text {[fluid] }}+2 \mathrm{H}_{2} \mathrm{O}^{\text {[fluid] }} \\
& 1 / 2 \mathrm{~S}_{2}{ }^{\text {ffluid] }}+\mathrm{O}_{2}=\mathrm{SO}_{2}{ }^{\text {ffluid] }} \\
& \mathrm{H}_{2} \mathrm{~S}^{\text {[fluid] }}+1 / 2 \mathrm{O}_{2}=1 / 2 \mathrm{~S}_{2}^{\text {ffluid] }}+\mathrm{H}_{2} \mathrm{O}^{\text {[fluid] }}
\end{aligned}
$$

Melt-gas equilibria were also considered:

$$
\begin{aligned}
& \mathrm{H}_{2} \mathrm{O}^{\text {[fluid] }}+\mathrm{O}^{2-[\text { melt }]}=2 \mathrm{OH}^{-[\text {melt }]} \quad \text { (C7) } \\
& \mathrm{CO}_{2}{ }^{\text {[fluid] }}+\mathrm{O}^{2-[\text { melt }]}=\mathrm{CO}_{3}{ }^{2-[\text { melt }]} \quad \text { (C8) } \\
& \mathrm{S}_{2}{ }^{\text {[fluid] }}+2 \mathrm{O}^{2-[\text { melt }]}=\mathrm{O}_{2}{ }^{\text {[gas] }}+2 \mathrm{~S}^{2-[\text { melt }]} \quad \text { (C9) } \\
& \mathrm{S}^{2-[\text { melt] }}+2 \mathrm{O}_{2}{ }^{\text {[gas] }}=\mathrm{SO}_{4}{ }^{2-[\text { melt] }} \quad \text { (C10) } \\
& 2 \mathrm{FeO}^{[\text {melt] }}+1 / 2 \mathrm{O}_{2}{ }^{\text {[gas] }}=\mathrm{Fe}_{2} \mathrm{O}_{3}{ }^{\text {[melt] }} \quad \text { (C11) }
\end{aligned}
$$

Equilibria (C1)-(C6) and (C10) were simultaneously solved at every given pressure and temperature, under the requirement that the amounts of $\mathrm{H}, \mathrm{S}, \mathrm{O}$ and $\mathrm{C}$ remain constant in the system (gas + melt + graphite). Seven redox couples were considered for each calculation, involving sulfur (with 3 different redox states), carbon (with 4 different redox states) and hydrogen (with 2 different redox states), together with iron (2 redox states). Each equilibrium constant for equilibria from (C1)-(C6) is compiled in Symonds and Reed (1993). Solubility laws for $\mathrm{H}_{2} \mathrm{O}$, and $\mathrm{CO}_{2}$ (equilibria (C7)-(C8)) were taken from lacono-Marziano et al. (2012b). Equilibrium (C9) is from Mavrogenes and O'Neill (1999), combined with Mungall \& Brenan (2014) to account for temperature effect, while sulfide-sulfate equilibrium (C10) is from Jugo et al. (2010). The ferric-ferrous equilibrium (C11) was computed after Kress and Carmichael (1991). The concentrations of reduced $\mathrm{C}$ species (e.g. $\mathrm{CO}, \mathrm{CH}_{4}$ ) in the basaltic melt was neglected in our calculations, as they are known to have very low solubility in a basaltic melt at 200-300 MPa (Pan et al. 1991; Morizet et al. 2010).

In conclusion, our approach combines existing experimental studies performed on specific volatiles into a multi-component model, under the assumption of gas-melt equilibrium. 


\section{$\underline{\text { Figure Captions }}$}

Fig.1: A) Geological map of the Tunguska Basin, showing the current distribution of effusive and intrusive rocks, and of the sediments of the Tungusskaya series; the purple areas show the approximate extent of the Devonian evaporite-bearing sediments at depth. Modified after Malich et al. (1974); Zharkov (1984). B) NW-SE cross section of the Kharaelakh and Talnakh intrusions modified after Naldrett (2004), and Li et al. (2009 b). C) Generalized stratigraphic column of the Noril'skTalnakh region modified after Zen'ko and Czamanske 1994b. The average thickness, the name and the rock types of the Silurian to Permian formations are shown. In purple the anhydrite-rich rocks, and in orange the terrigenous rocks. The stratigraphic position of the intrusions is also shown (Nor: Noril'sk I, Tal: Talnakh, L Tal: Lower Talnakh, L Nor: Lower Noril'sk, Kha: Kharaelakh); the bars in red represent the lower, ore-bearing part of the intrusions.

Fig.2: BSE images of the most representative sulfide saturated experimental samples without addition of anhydrite or coal $(a, b, c)$, consisting of glass, olivine, and sulfide globules. BSE images of the samples with anhydrite addition (d, e, f): sample \#4.5 (d) consists of glass, olivine, and sulfide globules far from anhydrite chips; sample \#5.2 (e, f) consists of glass, olivine, and Al-Fe-Mg-Cr-oxides (ox). See Table 2 for experimental conditions.

Fig.3: BSE images of the experimental samples with coal addition: sample \#6.3 (a, b, d) consists of glass, olivine, plagioclase (plg), clinopyroxene (cpx), and sulfide globules (sulf); sample \#4.3 (c, e) consists of glass, olivine (ol), plagioclase, and sulfide globules (sulf). Coal: coal residue, most likely graphite. See Table 2 for experimental conditions.

Fig.4: Sulfur contents dissolved in sulfide and sulfate saturated experimental silicate melts as a function of the oxygen fugacity at which the samples was equilibrated. The sulfur content of the sulfide-saturated melts of experiments \#4.3, \#6.2, and \#6.3, for which $\mathrm{fO}_{2}$ was not precisely determined, are also shown by the grey field. The red curve represents the calculations of the sulfur content at sulfide and sulfate saturation after Jugo (2009) for $\mathrm{T}=1300^{\circ} \mathrm{C}$ and $\mathrm{P}=1 \mathrm{GPa}$ (for $\mathrm{S}$ dissolved only as sulfide $=0.07$ wt. $\%$ ).

Fig.5: BSE image of sample \#4.5 (a), showing the dissolution of an anhydrite chip into the silicate melt: the clear areas mainly consist of glass, while the darker areas consist of glass, olivine and sulfide globules few microns in size. X-ray images obtained by EMP showing the distribution of Ca (b), $\mathrm{Fe}(\mathrm{c}), \mathrm{Si}(\mathrm{d}), \mathrm{S}(\mathrm{e})$, and $\mathrm{Mg}(\mathrm{f})$ in the same sample. $\mathrm{CaO}, \mathrm{FeO}, \mathrm{SiO}_{2}, \mathrm{~S}$, and $\mathrm{MgO}$ contents measured in 
the glass close to and far from anhydrite are also shown. The distribution of olivine crystals is clearly visible in (f), while that of sulfide droplets (red small spots) is less visible in (e).

Fig.6: Results of thermodynamic calculations simulating anhydrite assimilation up to 5.5 wt.\% in mafic magma containing 10.8 wt.\% FeO*. Evolution of the oxygen fugacity (a) at $80 \mathrm{MPa}$ for different temperatures; (b) at $1200{ }^{\circ} \mathrm{C}$ for different pressures; (c) at $1200^{\circ} \mathrm{C}$ and $80 \mathrm{MPa}$ for different initial proportions of fluid phase (consisting of $\mathrm{CO}_{2}$ ). Evolution of the total sulfur content of the melt (d) at $80 \mathrm{MPa}$ for different temperatures (the initial S content at sulfide saturation at 1300 and $1350^{\circ} \mathrm{C}$ is calculated following Fortin et al. 2015); (e) at $1200{ }^{\circ} \mathrm{C}$ for different pressures; (f) at $1200^{\circ} \mathrm{C}$ and 80 $\mathrm{MPa}$ for different initial proportions of fluid phase. Evolution of the reduced sulfur $\left(\mathrm{S}^{2-}\right)$ content of the melt (g) at $80 \mathrm{MPa}$ for different temperatures; (h) at $1200^{\circ} \mathrm{C}$ for different pressures; (i) at $1200^{\circ} \mathrm{C}$ and $80 \mathrm{MPa}$ for different initial proportions of fluid phase. Evolution of the oxidized sulfur $\left(\mathrm{S}^{6+}\right)$ content of the melt (j) at $80 \mathrm{MPa}$ for different temperatures; (k) at $1200^{\circ} \mathrm{C}$ for different pressures; (I) at $1200{ }^{\circ} \mathrm{C}$ and $80 \mathrm{MPa}$ for different initial proportions of fluid phase. The blue boxes indicate the field of sulfide saturation obtained by the experiments at $1200^{\circ} \mathrm{C}, 80 \mathrm{MPa}$ and $\mathrm{fO}_{2}<\mathrm{FMQ}-1$, while the pink boxes indicate the field of sulfate saturation obtained by the experiments at $1200^{\circ} \mathrm{C}, 80 \mathrm{MPa}$ and $\mathrm{fO}_{2}$ of $\mathrm{FMQ}+3.5$.

Fig.7: Evolution of the sulfur content of the melt as a function of oxygen fugacity for experiments at equilibrium conditions (black diamonds) and thermodynamic calculations (curves) at different pressures, temperatures and fluid phase contents, indicated by the legend. (a) $\mathrm{SO}_{3}{ }^{2-}$ assimilation, and (b) $\mathrm{CH}$ assimilation. In (a) the numbers indicate the amounts (in wt.\%) of $\mathrm{CaSO}_{4}$ assimilated, while in (b) the total amount of $\mathrm{CH}$ that has to be assimilated to reach sulfide saturation in the melt. The field of sulfate saturation in the melt ( $0.9 \pm 0.1 \mathrm{wt} . \% \mathrm{~S}$, according to the experimental results) is shown in pink. 
Table 1. Composition of the starting glass used in the experiments

Picritic starting glass

(39 EMP analyses)

\begin{tabular}{lc}
\hline $\mathrm{SiO}_{2}$ (wt.\%) & $48.0(4)$ \\
$\mathrm{TiO}_{2}$ (wt.\%) & $0.88(9)$ \\
$\mathrm{Al}_{2} \mathrm{O}_{3}$ (wt.\%) & $15.6(2)$ \\
$\mathrm{FeO}$ (wt.\%) & $10.8(5)$ \\
$\mathrm{MgO}$ (wt.\%) & $11.4(1)$ \\
$\mathrm{CaO}(w t . \%)$ & $10.8(1)$ \\
$\mathrm{Na}{ }_{2} \mathrm{O}(w t . \%)$ & $1.61(7)$ \\
$\mathrm{K}_{2} \mathrm{O}(w t . \%)$ & $0.60(6)$ \\
$\mathrm{Total}^{2}$ & $99.7(8)$ \\
\hline
\end{tabular}


Table 2. Experimental conditions and results

\begin{tabular}{|c|c|c|c|c|c|c|c|c|c|c|c|c|c|c|}
\hline Sample & Glass & $\begin{array}{r}\text { Anhydrite }^{a} \\
\text { (wt.\%) }\end{array}$ & $\begin{array}{c}\text { Coal }^{\mathrm{a}} \\
\text { (wt.\%) }\end{array}$ & $\begin{array}{r}\text { Duration } \\
\text { (min) }\end{array}$ & $\mathrm{fO}_{2}$ & phases & $\begin{array}{l}\text { Fluid }^{\mathrm{b}} \\
\text { (wt.\%) }\end{array}$ & $\begin{array}{c}\mathrm{SiO}_{2}{ }^{\mathrm{c}} \\
\text { (wt.\%) }\end{array}$ & $\begin{array}{l}\mathrm{FeO} * \mathrm{c} \\
\text { (wt.\%) }\end{array}$ & $\begin{array}{l}\mathrm{MgO}^{\mathrm{c}} \\
\text { (wt.\%) }\end{array}$ & $\begin{array}{r}\mathrm{CaO}^{\mathrm{c}} \\
\text { (wt.\%) }\end{array}$ & $\begin{array}{r}S^{c} \\
\text { (wt.\%) }\end{array}$ & $\begin{array}{l}\text { Total }^{\mathrm{d}} \\
\text { (wt.\%) }\end{array}$ & $\mathrm{Fo}^{\mathrm{e}}$ \\
\hline$\# 4.5$ & SG+0.5 wt. $\% \mathrm{~S}$ & 11.0 & - & 10 & nd & gl+ol+sulf & 0.6 & $\begin{array}{r}47.6 \\
(9)\end{array}$ & $\begin{array}{r}10.0 \\
(7)\end{array}$ & $\begin{array}{r}10.7 \\
(6)\end{array}$ & $\begin{array}{l}13 \\
(1)\end{array}$ & $\begin{array}{l}0.6 \\
(3)\end{array}$ & $\begin{array}{l}94 \\
\text { (2) }\end{array}$ & $\begin{array}{r}0.866 \\
(7)\end{array}$ \\
\hline \#5.2 & SG & 7.0 & - & 160 & $\begin{array}{r}F M Q+3.5 \\
( \pm 0.5)\end{array}$ & gl+ol+ox & 0.5 & $\begin{array}{r}47.5 \\
(3)\end{array}$ & $\begin{array}{l}9.8 \\
(4)\end{array}$ & $\begin{array}{r}10.9 \\
(3)\end{array}$ & $\begin{array}{r}13.0 \\
(2)\end{array}$ & 0.9 & $\begin{array}{r}94.7 \\
(7)\end{array}$ & $\begin{array}{r}0.895 \\
(4)\end{array}$ \\
\hline$\# 4.3$ & SG+0.5 wt. $\% \mathrm{~S}$ & - & 7.8 & 10 & nd & $\begin{array}{r}\text { gl+ol+sulf } \\
+ \text { plg }\end{array}$ & 3.3 & $\begin{array}{r}50.6 \\
(9)\end{array}$ & $\begin{array}{l}9.6 \\
(6)\end{array}$ & $\begin{array}{l}8.8 \\
(3)\end{array}$ & $\begin{array}{r}11.7 \\
(6)\end{array}$ & $\begin{array}{r}0.08 \\
(2)\end{array}$ & $\begin{array}{r}97.1 \\
(8)\end{array}$ & $\begin{array}{r}0.820 \\
(5)\end{array}$ \\
\hline \#6.3 & $\# 5.2$ & - & 6.1 & 145 & $<F M Q-3$ & $\begin{array}{r}\text { gl+ol+sulf } \\
+ \text { plg+cpx }\end{array}$ & 8.1 & $\begin{array}{r}50.5 \\
(5)\end{array}$ & $\begin{array}{l}5.6 \\
(7)\end{array}$ & $\begin{array}{l}9.4 \\
(2)\end{array}$ & $\begin{array}{r}15.0 \\
(2)\end{array}$ & $\begin{array}{r}0.07 \\
(1)\end{array}$ & $\begin{array}{r}98.5 \\
(7)\end{array}$ & $\begin{array}{r}0.906 \\
(4)\end{array}$ \\
\hline$\# 4.1$ & SG+0.5 wt.\%S & - & - & 10 & $\begin{array}{r}F M Q \\
( \pm 0.3)\end{array}$ & gl+ol+sulf & 0.3 & $\begin{array}{r}48.8 \\
(4)\end{array}$ & $\begin{array}{r}10.2 \\
(5)\end{array}$ & $\begin{array}{r}10.5 \\
(2)\end{array}$ & $\begin{array}{r}11.4 \\
(2)\end{array}$ & $\begin{array}{r}0.14 \\
(3)\end{array}$ & $\begin{array}{r}95.9 \\
(6)\end{array}$ & $\begin{array}{r}0.859 \\
(8)\end{array}$ \\
\hline$\# 6.2$ & SG+0.5 wt. $\% S$ & - & - & 145 & $<\mathrm{FMQ}-1$ & gl+ol+sulf & 0.7 & $\begin{array}{r}50.7 \\
(4)\end{array}$ & $\begin{array}{l}6.5 \\
\text { (3) }\end{array}$ & $\begin{array}{r}11.2 \\
(2)\end{array}$ & $\begin{array}{r}11.3 \\
(2)\end{array}$ & $\begin{array}{r}0.07 \\
(1)\end{array}$ & $\begin{array}{r}96.3 \\
(6)\end{array}$ & $\begin{array}{r}0.899 \\
(7)\end{array}$ \\
\hline \#36.5 & SG+3 wt. $\%$ S & - & - & 180 & $\begin{array}{r}\text { FMQ }-0.5 \\
( \pm 0.2)\end{array}$ & gl+ol+sulf & 0.3 & $\begin{array}{r}51.0 \\
(5)\end{array}$ & $\begin{array}{l}5.7 \\
(5)\end{array}$ & $\begin{array}{r}10.3 \\
(2)\end{array}$ & $\begin{array}{r}12.0 \\
(2)\end{array}$ & $\begin{array}{r}0.10 \\
(2)\end{array}$ & $\begin{array}{r}97.7 \\
(8)\end{array}$ & $\begin{array}{r}0.915 \\
(3)\end{array}$ \\
\hline \#52.1 & SG+5 wt. $\%$ S & - & - & 180 & $\begin{array}{r}F M Q+0.6 \\
( \pm 0.3)\end{array}$ & gl+ol+sulf & 0.9 & $\begin{array}{r}49.1 \\
(4)\end{array}$ & $\begin{array}{l}9.0 \\
(4)\end{array}$ & $\begin{array}{r}10.7 \\
(1)\end{array}$ & $\begin{array}{r}11.1 \\
(1)\end{array}$ & $\begin{array}{r}0.22 \\
(3)\end{array}$ & $\begin{array}{r}97.3 \\
(4)\end{array}$ & $\begin{array}{r}0.896 \\
(4)\end{array}$ \\
\hline \#59.3 & SG+3 wt.\% S & - & - & 180 & $\begin{array}{r}F M Q+1.5 \\
( \pm 0.3)\end{array}$ & & 0.8 & $\begin{array}{r}48.6 \\
(5)\end{array}$ & $\begin{array}{l}9.7 \\
(6)\end{array}$ & $\begin{array}{l}9.9 \\
(2)\end{array}$ & $\begin{array}{r}11.1 \\
(2)\end{array}$ & $\begin{array}{r}0.40 \\
(6)\end{array}$ & $\begin{array}{l}97 \\
(2)\end{array}$ & $\begin{array}{r}0.885 \\
(5)\end{array}$ \\
\hline$\# 44.2$ & SG+5 wt. $\%$ S & - & - & 30 & $\begin{array}{r}\mathrm{FMQ}+0.8 \\
( \pm 0.3)\end{array}$ & gl+ol+sulf & 1.7 & $\begin{array}{r}50.5 \\
(4)\end{array}$ & $\begin{array}{l}7.2 \\
(5)\end{array}$ & $\begin{array}{r}10.0 \\
(2)\end{array}$ & $\begin{array}{r}11.6 \\
(2)\end{array}$ & $\begin{array}{r}0.27 \\
(4)\end{array}$ & $\begin{array}{r}97.6 \\
(9)\end{array}$ & $\begin{array}{r}0.899 \\
(3)\end{array}$ \\
\hline
\end{tabular}

All experiments were run at $1200^{\circ} \mathrm{C} \pm 2^{\circ} \mathrm{C}$ and $75 \pm 7 \mathrm{MPa}$.

${ }^{a}$ Amounts of anhydrite or coal loaded in the capsule. ${ }^{b}$ Amounts of fluid phase in the capsule estimated by weight loss. ${ }^{\mathrm{c}} \mathrm{Glass}$ compositions by EMPA, normalized to 100 (complete analyses are in the Supplementary Information). ${ }^{d}$ Original total of the EMPA. ${ }^{\mathrm{e}}$ Forsterite content in olivine. Numbers in brackets are the standard deviation on the last decimal unit; nd: not determined. 


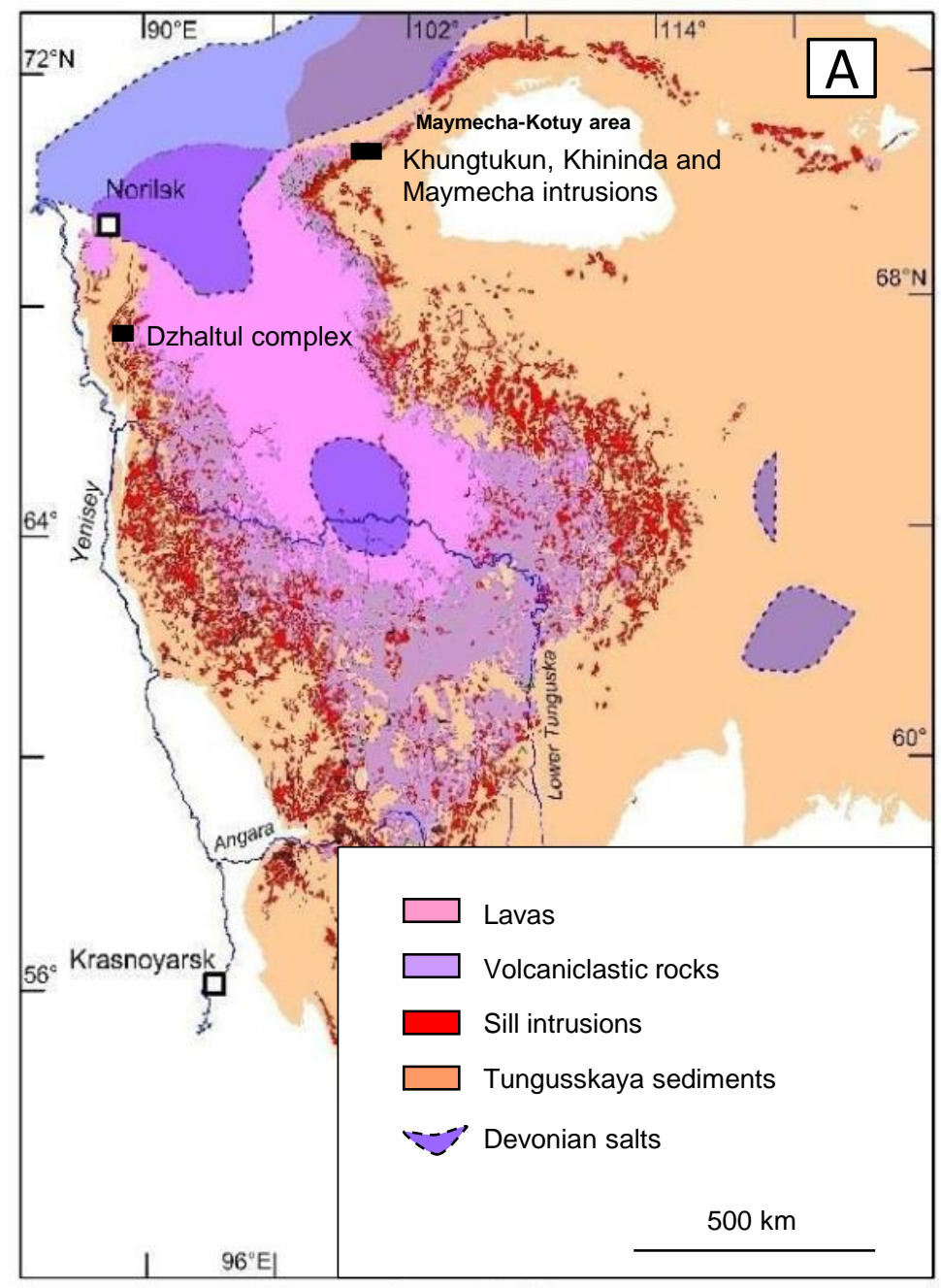

\begin{tabular}{|c|c|c|c|c|}
\hline Upper & $\mathrm{P}_{2} \mathrm{NV}$ & & $\begin{array}{l}80- \\
140 \mathrm{~m}\end{array}$ & $\begin{array}{l}\text { Ivakinsky suite; } \\
\text { lavas and tuffs }\end{array}$ \\
\hline Permlan & & & & \\
\hline 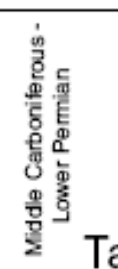 & $\mathrm{C}_{2}-\mathrm{P}_{2}$ & & $\begin{array}{r}280- \\
330\end{array}$ & $\begin{array}{l}\text { Tungusskaya series; } \\
\text { siltstones, sandstones, } \\
\text { coals, conglomerates }\end{array}$ \\
\hline Upper & $\mathrm{D}_{3} \mathrm{kl}$ & $\frac{1}{51}$ & $\begin{array}{r}140- \\
180\end{array}$ & $\begin{array}{l}\text { Kalargonsky formation; } \\
\text { dolomites, limestones, } \\
\text { dolomitic marls } \\
\text { al }\end{array}$ \\
\hline & $\mathrm{D}_{3} \mathrm{nk}$ & & $2-80$ & $\begin{array}{l}\text { Nakokhozsky formation; } \\
\text { dolomitic marls, anhydrites }\end{array}$ \\
\hline & $\mathrm{D}_{2} \mathrm{Jk}$ & & $12-40$ & $\begin{array}{c}\text { Yuktinssy formation; } \\
\text { dolomites }\end{array}$ \\
\hline $\begin{array}{l}\text { Mlddle } \\
\text { Devonlan }\end{array}$ & $\mathrm{D}_{1-2} \mathrm{mt}$ & $\frac{x}{10}$ & $\begin{array}{l}110- \\
210\end{array}$ & $\begin{array}{l}\text { Manturovsky formation; } \\
\text { dolomitic marls, dolomites, } \\
\text { anhydrites, marls, lenses } \\
\text { of salt ( } \mathrm{NaCl})\end{array}$ \\
\hline \multirow{5}{*}{$\begin{array}{l}\text { Lower } \\
\text { Devonlan }\end{array}$} & $D_{1} R$ & & $\begin{array}{r}110- \\
150 \\
\end{array}$ & $\begin{array}{c}\text { Razvedochninsky formation; } \\
\text { argillites, layers and lenses } \\
\text { of limestones, siltstones, } \\
\text { sandstones }\end{array}$ \\
\hline & $\mathrm{D}_{1} \mathrm{kr}$ & & $\begin{array}{l}62- \\
85\end{array}$ & Kureysky formation; marls \\
\hline & $\mathrm{D}_{1} \mathrm{zb}$ & 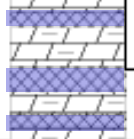 & $\begin{array}{r}110- \\
140\end{array}$ & $\begin{array}{l}\text { Zubovsky formation; } \\
\text { dolomitic marls, } \\
\text { anhydrites }\end{array}$ \\
\hline & $\mathrm{D}_{1} \mathrm{hr}$ & $\frac{1}{2 x y x}$ & $30-90$ & $\begin{array}{l}\text { Khrebtousky formation; } \\
\text { dolomitic marls, } \\
\text { anhydrites, dolomites }\end{array}$ \\
\hline & $\mathrm{D}_{1} \mathrm{Jm}$ & 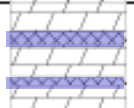 & $\begin{array}{l}50- \\
100\end{array}$ & $\begin{array}{l}\text { Yampakhtinsky formation; } \\
\text { dolomites with layers of } \\
\text { anhydrite }\end{array}$ \\
\hline $\begin{array}{l}\text { Upper } \\
\text { Sllurlan }\end{array}$ & $\mathrm{S}_{2} \mathrm{ps}$ & $\frac{1}{6 x+\frac{1}{x} x \times x}$ & $\begin{array}{l}96- \\
105\end{array}$ & $\begin{array}{l}\text { Postichny formation; dolomitic } \\
\text { marls, dolomites, anhydrites }\end{array}$ \\
\hline
\end{tabular}

Fig.1

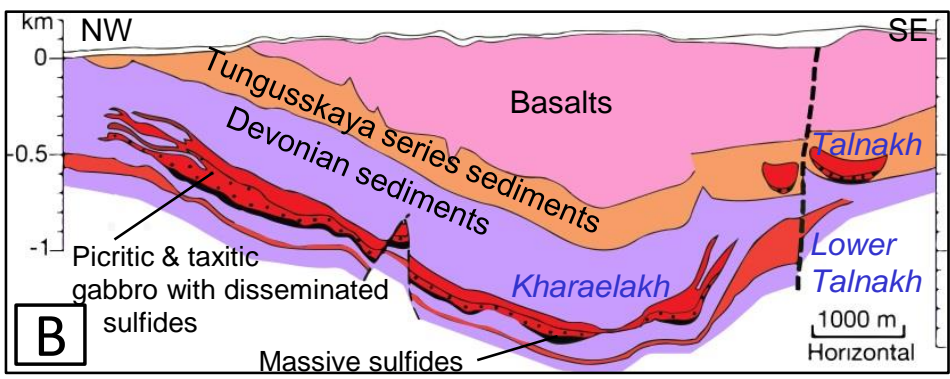



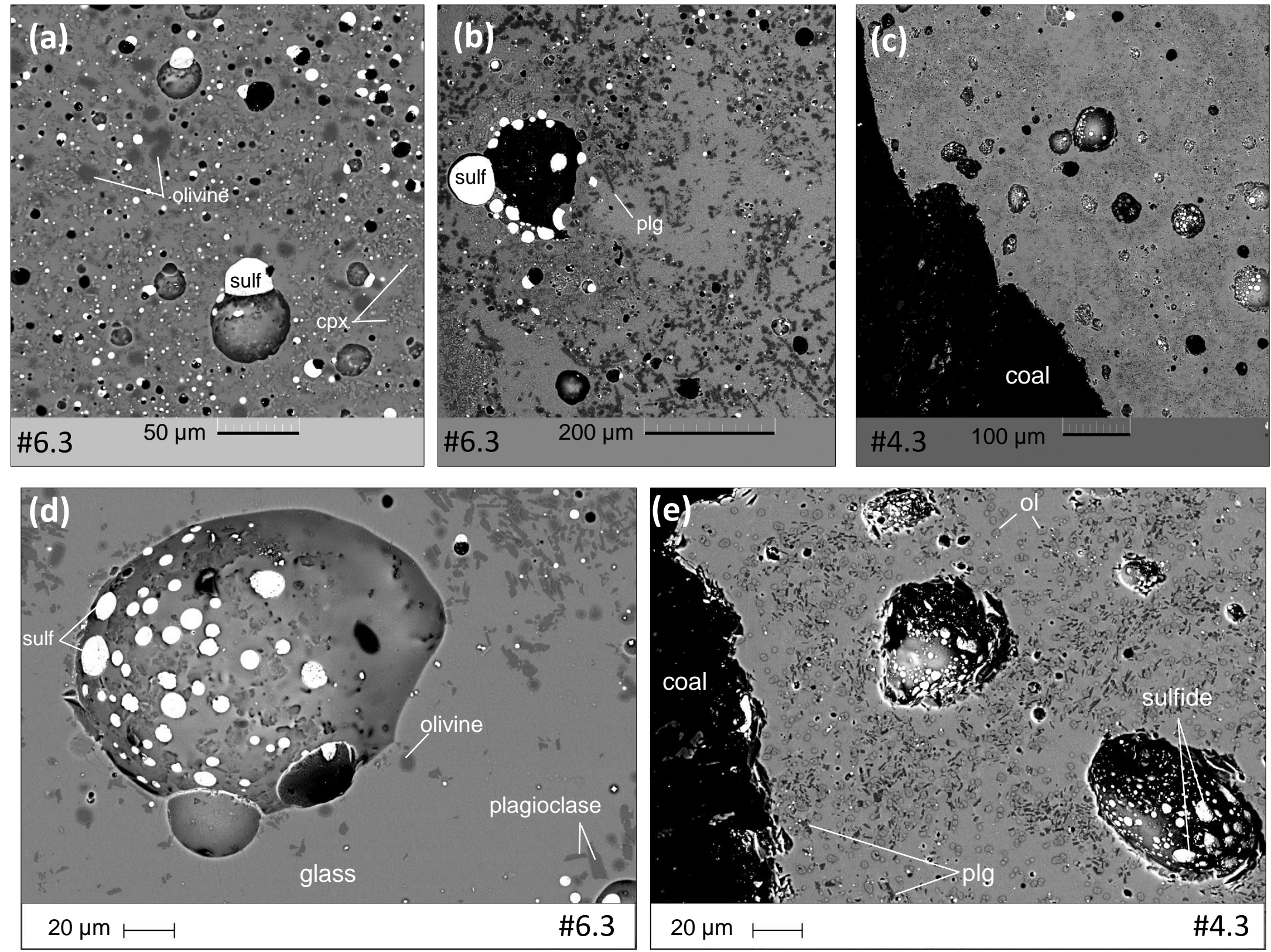

Fig.3 


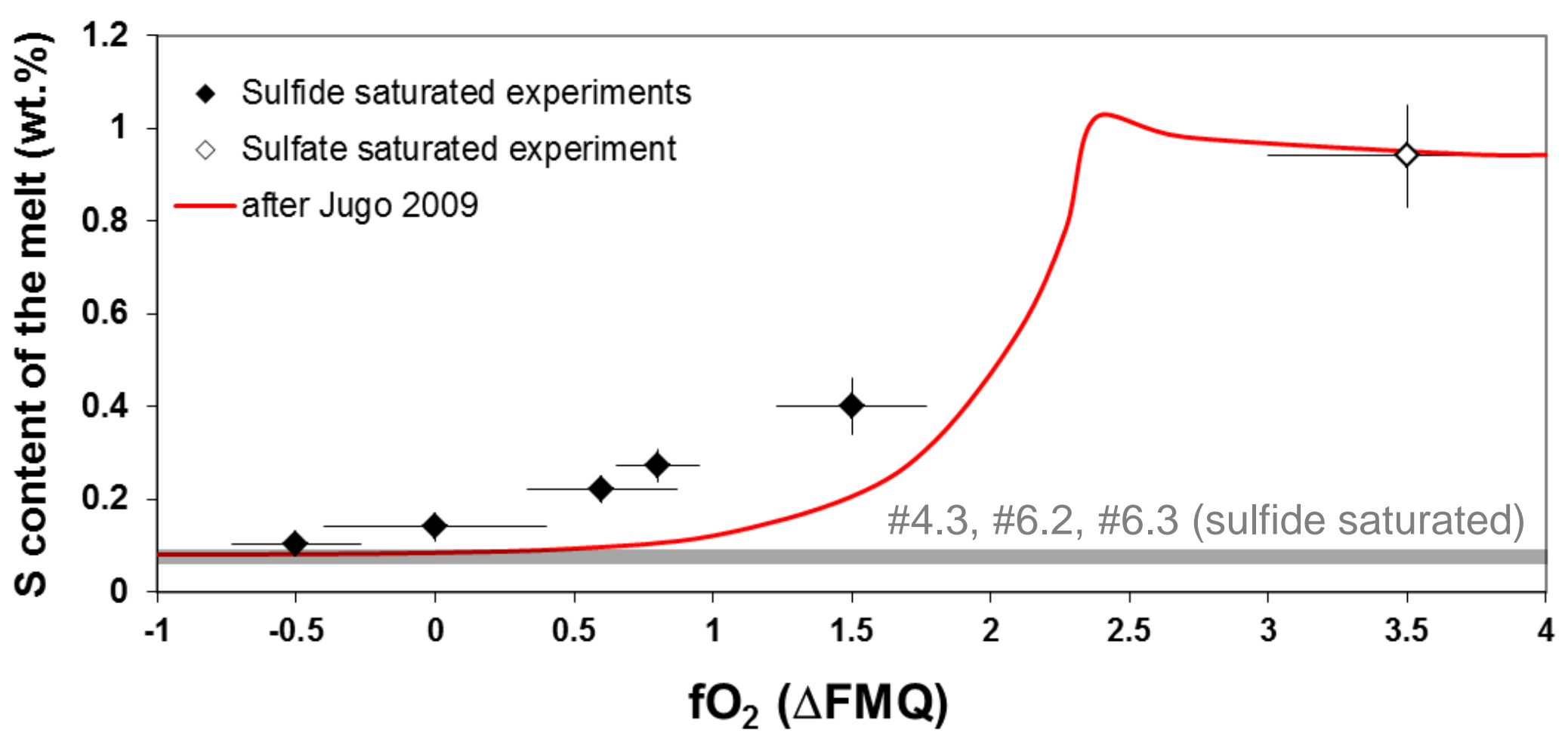

Fig. 4 


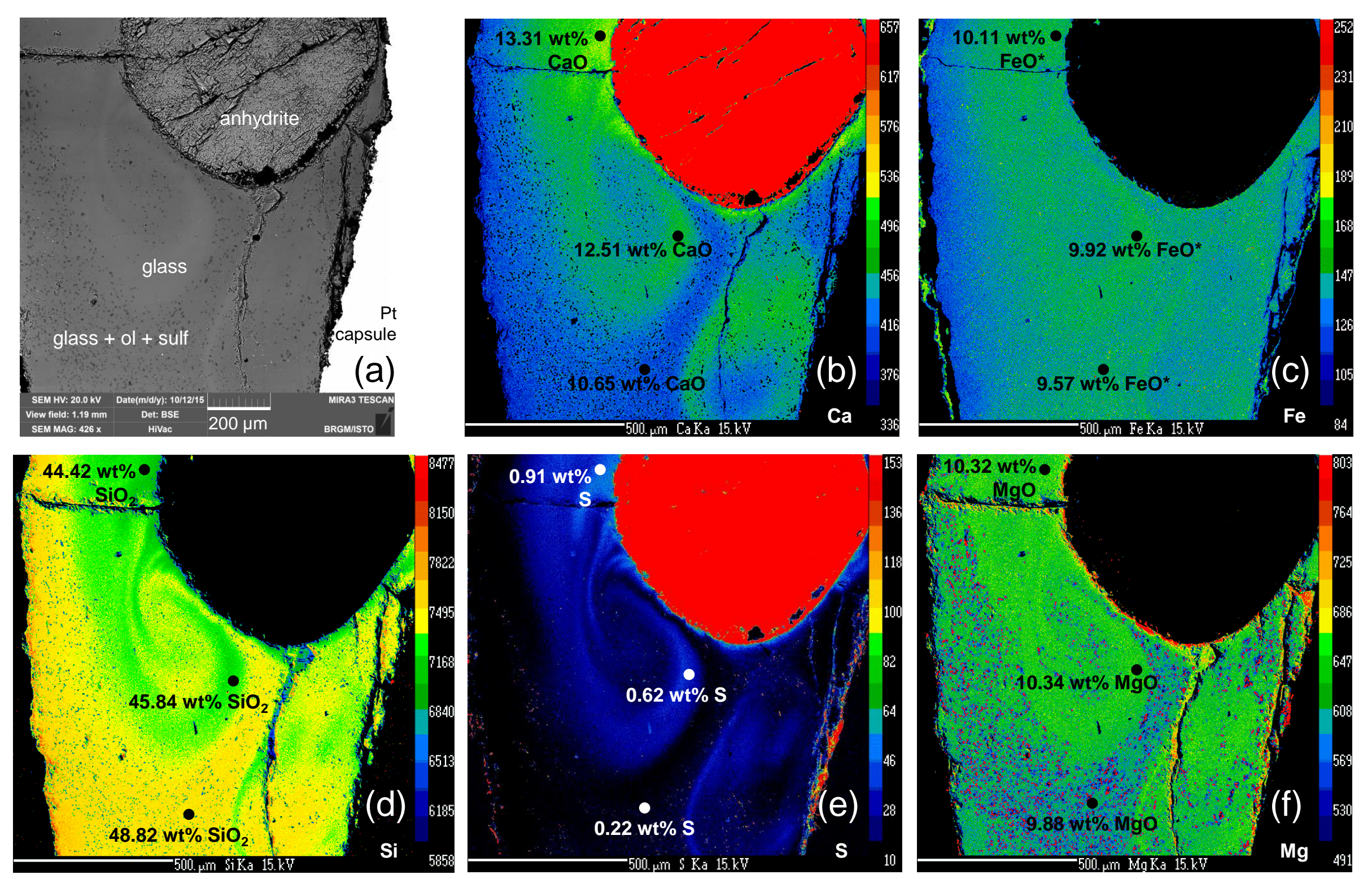

Fig.5 


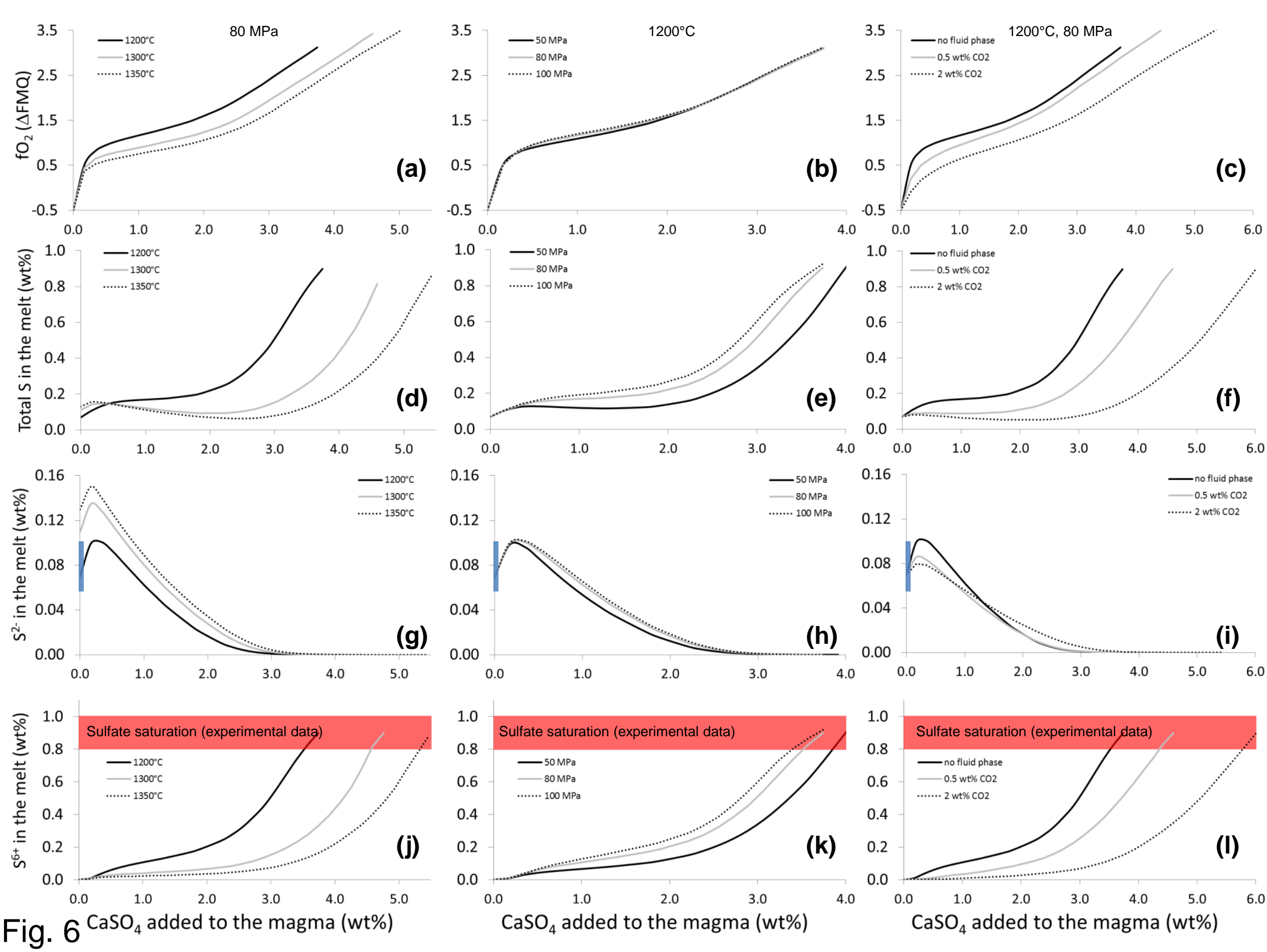



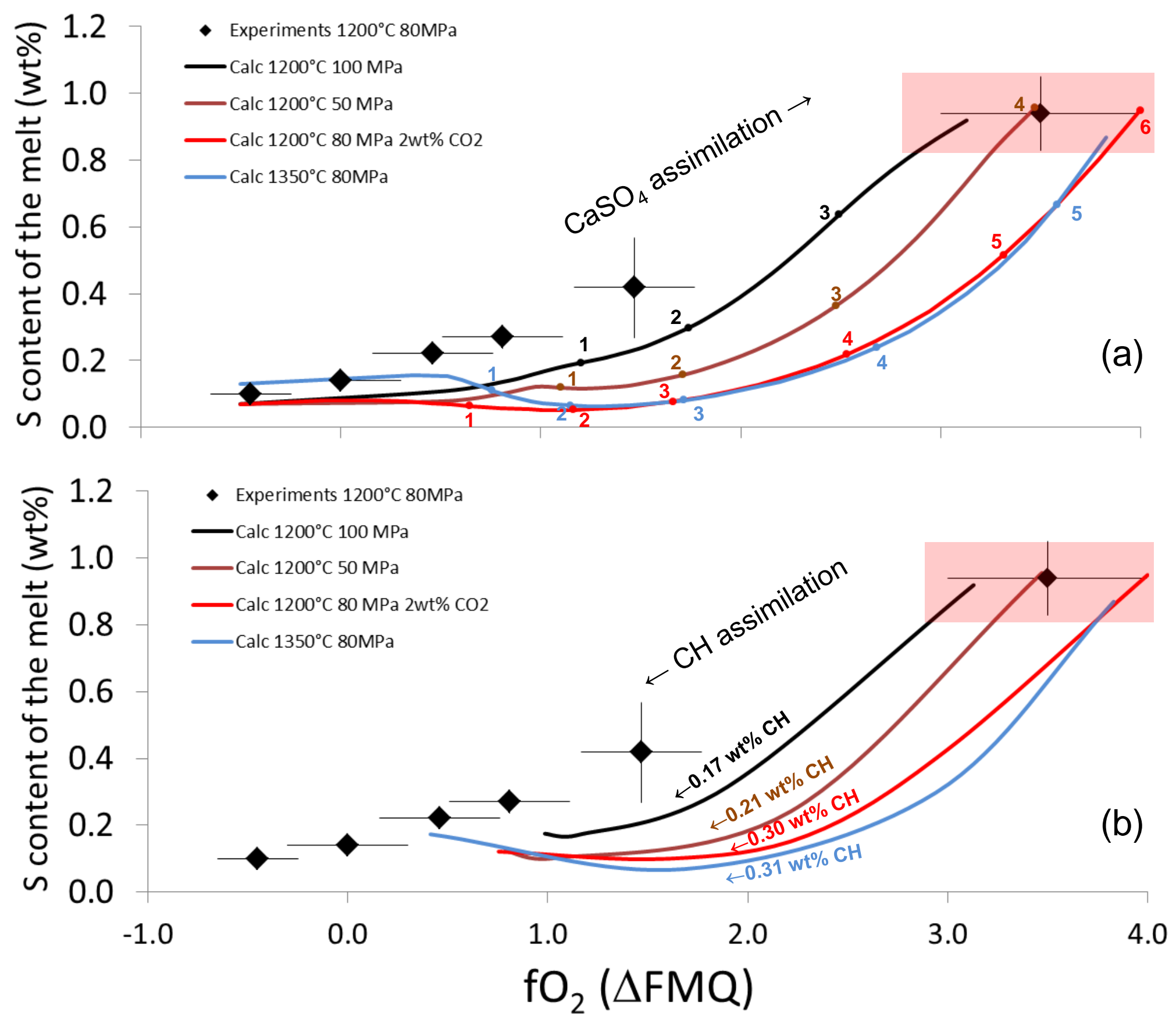

Fig.7 


\section{Highlights}

- The assimilation of evaporitic and carbonaceous rocks by mafic-ultramafic magmas is investigated.

- Sulfate assimilation oxidized the magma, increases its sulfur content and prevents sulfide saturation.

- Organic matter assimilation reduces the magma and favors crystallization and sulfide saturation.

- Combined sulfate and organic matter assimilation is proposed to produce Noril'sk ore deposits. 


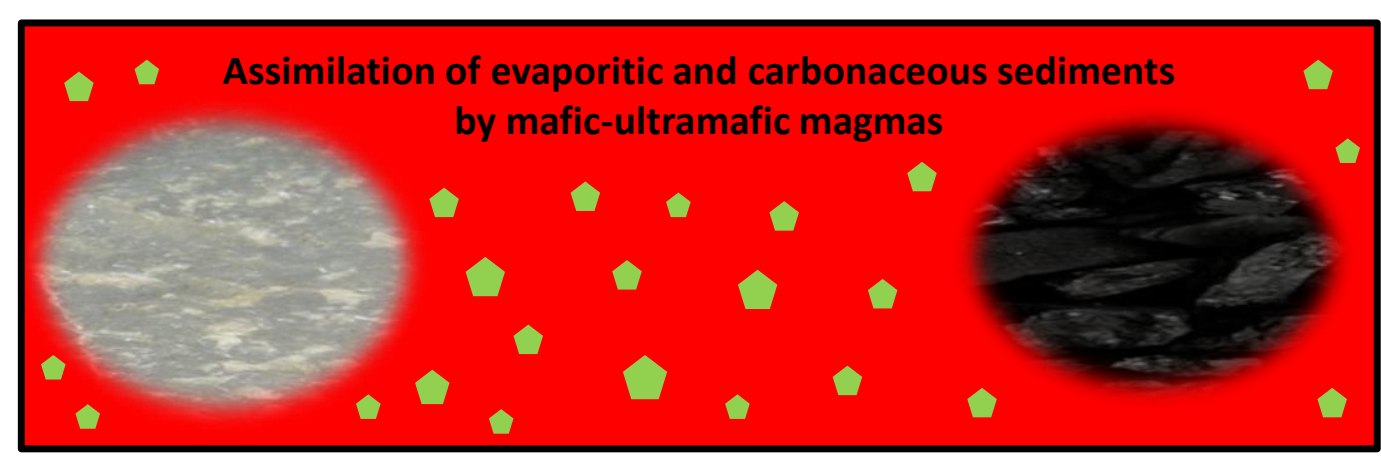

Methods

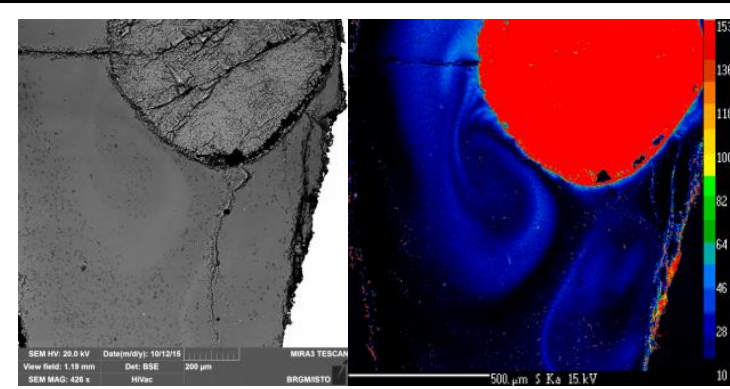

Experimental petrology

Thermodynamic modeling

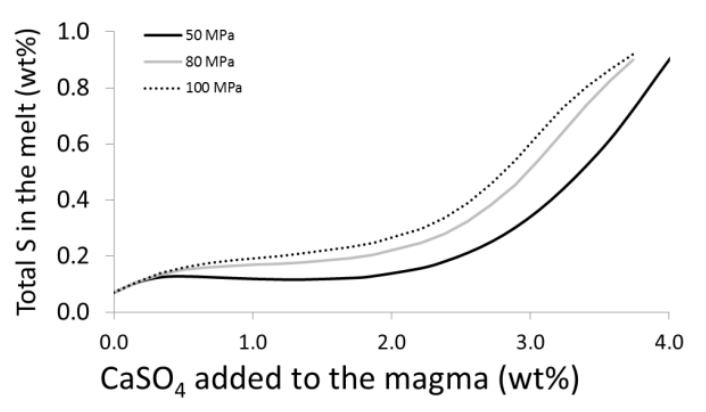

Application

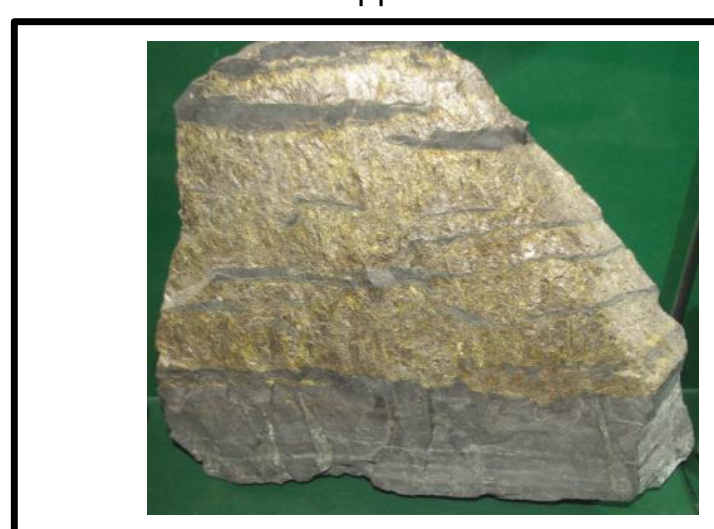

Magmatic sulfide ores of the Noril'sk-Talnakh region

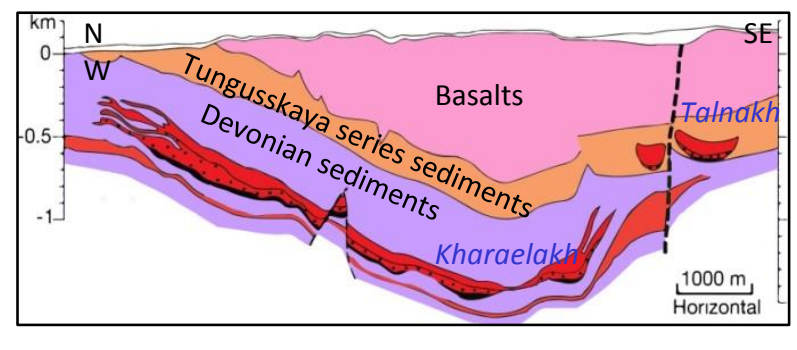

